\title{
Arsenic Mobility in As-Containing Soils from Geogenic Origin: Fractionation and Leachability
}

\author{
Diego Martiñá-Prieto (D), Javier Cancelo-González $(\mathbb{D}$, and María Teresa Barral $\mathbb{D}$ \\ Departamento de Edafoloxía e Química Agrícola, Facultade de Farmacia, Campus Vida, Universidade de \\ Santiago de Compostela, 15782 Santiago de Compostela, Spain \\ Correspondence should be addressed to Javier Cancelo-González; javier.cancelo@usc.es
}

Received 6 September 2017; Accepted 24 December 2017; Published 12 February 2018

Academic Editor: Nabeel K. Niazi

Copyright (C) 2018 Diego Martiñá-Prieto et al. This is an open access article distributed under the Creative Commons Attribution License, which permits unrestricted use, distribution, and reproduction in any medium, provided the original work is properly cited.

\begin{abstract}
The lithogenic arsenic in soils of the Anllóns River basin (Spain) was quantified, its chemical fractions were determined, and its leachability characteristics were compared under various experimental conditions. Fifty soil samples of $\mathrm{C}$ horizons, sampling an area of $50 \mathrm{~km}^{2}$ along the river course, were submitted to an exploratory analysis. Pseudo-total arsenic ranged between 2 and $489 \mathrm{mg} \mathrm{kg}$. Arsenic leachability using the standard methods DIN 38414-S4 and TCLP was less than $0.25 \%$ of pseudo-total As. Then the effect of $\mathrm{pH}(3,6$, and 9$)$, solid : liquid $(\mathrm{S}: \mathrm{L})$ ratio $(1: 10$ and $1: 50)$, phosphate $(10 \mathrm{mM})$, and contact time $(24$ and $240 \mathrm{~h})$ on arsenic mobilization was studied in nine soils with the highest As concentration. Arsenic mobilization increased at alkaline $\mathrm{pH}$ and lower $S: L$ ratio; the most decisive factor was the addition of phosphate, increasing arsenic leachability up to 1,000 times, and this increased even 2.3 times when the contact time was extended from 24 hours to 240 hours. The results suggest that the mobilization of arsenic may be underestimated in short-term water leaching tests and that the environmental conditions favouring arsenic mobilization should be taken into account for a sound evaluation of the transfer risk of arsenic towards aquatic ecosystems.
\end{abstract}

\section{Introduction}

Arsenic (As) is a metalloid widely distributed in natural environments [1]. In the earth's crust, As is the 20th most abundant trace element [2] whose average concentration has been fixed at $1.7 \mathrm{mg} \mathrm{kg}^{-1}$ [3]. In soils, the baseline As concentration is generally in the order of $5-10 \mathrm{mg} \mathrm{kg}^{-1}[1]$, although the concentrations in soils developed on deposits of sulphides can reach hundreds of $\mathrm{mg} \mathrm{kg}^{-1}$. In particular, arsenic is frequently a significant component in gold deposits, and gold mining has frequently been associated with arsenic contamination. The processing of gold bearing sulphide minerals which contain arsenopyrite and other complex arsenic sulphide minerals results in arsenic containing emissions and effluents which must be given careful consideration in relation to clean air and clean water standards. In fact, there are numerous cases at the global level where gold mining operations have caused a release and redistribution of arsenic into the environment [4-13].
The occurrence of geogenic As represents a major concern for groundwater quality in many countries [14]. Arsenic mobilization from rocks and soils, as well as its subsequent incorporation into aquatic systems, is of environmental concern because this is a highly toxic element that poses a serious threat to human and ecosystem health, especially as a result of the contamination of drinking water and food $[1,15,16]$. Several processes have been identified as being responsible for the mobilization of As from the solid phase to the aqueous phase: ion displacement, desorption (or limited sorption) at $\mathrm{pH}$ values above 8.5 , reduction of arsenate to arsenite, and mineral dissolution, particularly reductive dissolution of $\mathrm{Fe}$ and Mn (hydr)oxides [17].

Pseudo-total As concentrations are not a good indicator of mobilization and potential environmental impact because As fractions differ in their solubility, particularly under different environmental conditions. Fractionation studies and leaching tests may help to assess arsenic mobilization and potential risk of transfer to aqueous systems. Sequential 
extraction procedures (SEP), such as those of Lombi et al. [18] or Wenzel et al. [19], make it possible to distinguish trace element fractions with different solubility, which are empirically related to mobilization classes [20]. In turn, leaching tests are used to predict both the potential mobilization of metals and metalloids to groundwater and their bioavailability to plants under natural conditions [21]. Standard tests have been developed for the evaluation of leachability that are mainly based on a washing in water under a specific soil : extractant ratio and contact time. Nevertheless, based on the geochemical characteristics of arsenic, we hypothesize that experimental conditions may drastically affect its solubility and consequently the result of this evaluation. To our knowledge, limited work has been carried out on lithogenic arsenic leaching experiments in soils [22-27] and references on As leachability are mostly focused on polluted soils of anthropic origin, mine soils and wastes, or other types of residues.

In this study, pseudo-total As contents, chemical fractions, and As mobilization under various experimental conditions were determined in soils from the Anllóns basin, where high geogenic As concentrations were detected, with the final aim of evaluating the potential risk of As transfer to aqueous systems. The results of this study would be of interest to achieve a more comprehensive knowledge of arsenic pollution in the area under study, which is partly considered a Site of Community Importance, as defined in the European Commission Habitats Directive (92/43/EEC). The study would be also of general interest to evaluate arsenic mobilization in different environmental scenarios and to design stabilization/rehabilitation strategies in polluted areas. Also, refining of leaching tests based on the results of this study may be applied for the assessment of the environmental impact of mining operations which imply soil remobilization and accumulation in mine spoils, with risk of lixiviation of arsenic to water.

\section{Materials and Methods}

2.1. Study Area. The Anllóns River is located in the region of Galicia (NW Spain); it has a length of about $63 \mathrm{~km}$ and flows into the Atlantic Ocean via the Laxe-Ponteceso Ría (Figure 1). The river drains a rural catchment of $516 \mathrm{~km}^{2}$ mainly dedicated to agriculture, forestry, and cattle raising activities. Two main human settlements are located in the catchment: Carballo, with a population of over 31,000, and Ponteceso, with a population of about 6,000 . The river runs over schists in the upper area, turning into a smooth profile in the middle area of the river, characterized by basic rocks (gabbros and amphibolites). Finally, the lower stretch of the river runs over two-mica granite, followed by biotitic gneiss at the mouth, where the largest area of alluvial materials is also found [28] (Figure 1). The most abundant soil type in the catchment is Cambic Umbrisol [29]. In the areas of scarce organic matter, ochric A-horizons are recognized, resulting in Dystric and Ferralic Cambisols. Leptosols and Regosols are also found in steep areas of the catchment, and Fluvisols along the fluvial banks.
In the catchment, high arsenic concentrations have been detected in various environmental compartments, due to the presence of arsenopyrite (AsFeS) mineralizations associated with gold ores in hydrothermal quartz veins [30]. Arsenic concentrations in the rocks of the area are usually around $1 \%$, but in mineralized zones with semimassive arsenopyrite they can reach up to $10 \%$. High As concentrations have been found in the bed sediments of the Anllóns River, downstream of the mineralized area, with a maximum of $264 \mathrm{mg} \mathrm{kg}^{-1}$, which have been attributed to natural geogenic arsenic enrichment, exacerbated by gold mining activities carried out since Roman times [31-33]. At some points along the river course, these high As concentrations have been identified as being responsible for ecotoxicity $[34,35]$. Arsenic concentrations exceeding ten to sixty times the legal limit for As in drinking water, set at $10 \mu \mathrm{g} \mathrm{L}^{-1}$ by WHO [36], have been detected in groundwater near the mineralized area. Also, increased arsenic levels have also been detected in the river water, downstream of the mining area and at the river mouth [37]. However, in spite of these evidences, the arsenic content, chemical fractions, and leachability in the soils of the Anllóns basin have not been studied so far, although they may contribute significantly to As in groundwater and in the riverine ecosystem, posing a potential risk for environment and human health.

With the purpose of achieving the defined objectives of this study, the experimental procedure outlined in Figure 2 has been followed.

2.2. Exploratory Analysis. For the identification of lithogenic As enrichment, a set of fifty soil samples was selected from the "Geochemical Atlas of Galicia" collection [38], made up of approximately 30,000 samples, one per square kilometre, covering the entire territory of this region. Samples were taken from $\mathrm{C}$ soil horizons to detect lithogenic concentrations of several elements without any disturbance from exogenous contamination. The $\mathrm{C}$ soil horizons were sampled in the central $10 \mathrm{~cm}$, whose lower limit is generally between 60 and $80 \mathrm{~cm}$ depth, with the exception of the soils developed on basic rocks whose lower limit is approximately between 80 and $120 \mathrm{~cm}$ depth. Samples were taken using probes or directly from the soil profile exposed in roadside talus after careful elimination of the outer $25 \mathrm{~cm}$. The samples selected in the present work covered an area of $50 \mathrm{~km}^{2}$ at both sides of the Anllóns River course, with a more comprehensive study in the As-Au mineralized area. Soil samples from the collection, which had been previously milled and passed through a $200 \mu \mathrm{m}$ sieve and preserved in dry and dark conditions in air tight containers, were milled again in an agate mortar and pestle and passed through a $50 \mu \mathrm{m}$ sieve to carry out the corresponding analyses. In these conditions of preservation, it is not expected that there have been changes in the concentration of the element or in its speciation.

2.2.1. Pseudo-Total Arsenic Concentrations. Pseudo-total As was determined by X-ray Fluorescence Spectrometry (custom built, equipped with a Philips high-voltage generator and a Mo anode of $2.2 \mathrm{~kW}$ as the X-ray source). Certified reference 


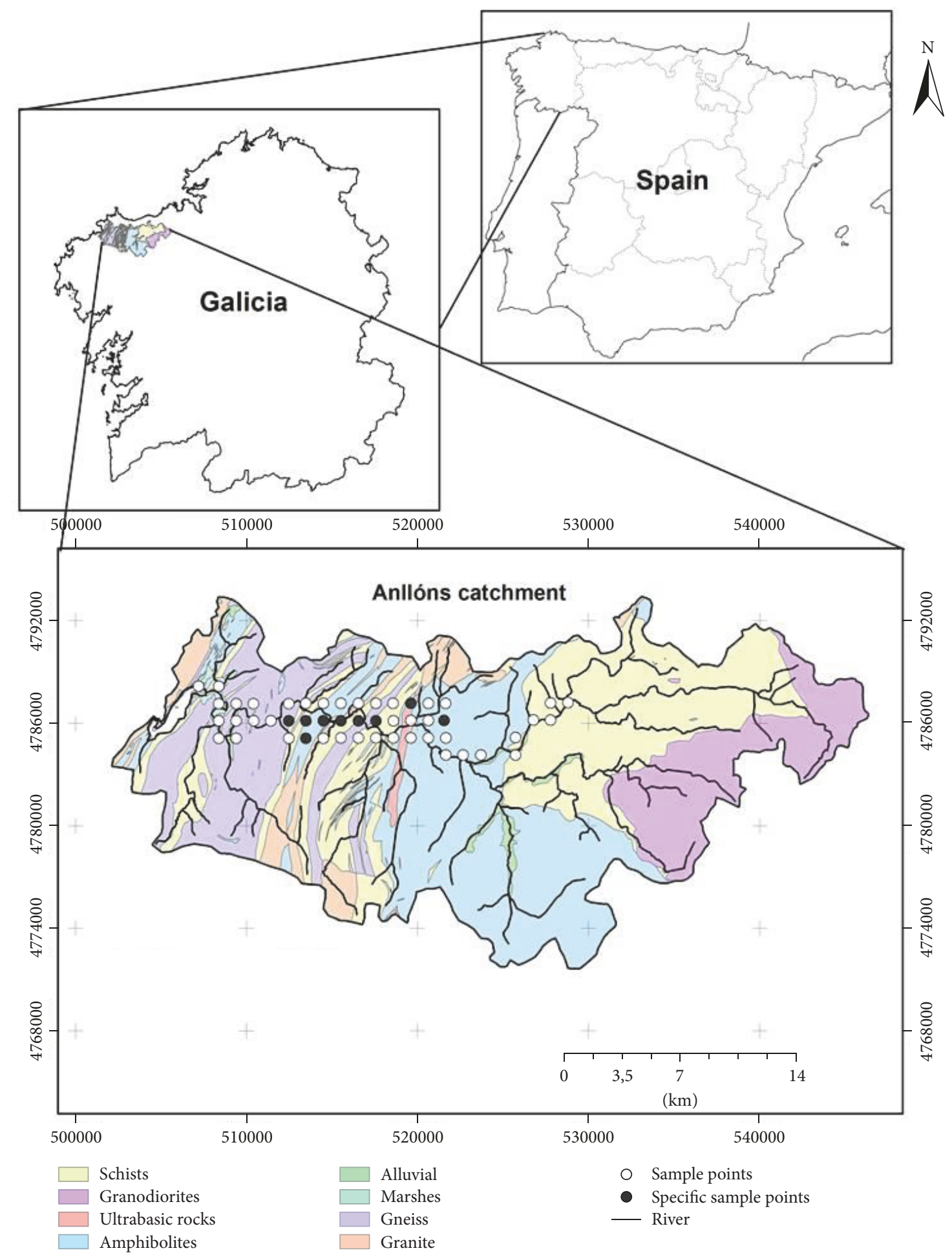

FIGURE 1: Location and geology of the Anllóns River catchment and location of the sampling points for the exploratory analysis and detailed specific analysis.

material BCR ${ }^{\circledR}-277 \mathrm{~b}$ (European Commission, Joint Research Centre, Geel, Belgium) was employed to check the accuracy of pseudo-total As measurements. The As concentration $\left(\mathrm{mg} \mathrm{kg}^{-1}\right)$ obtained for this certified reference material was $45.4 \pm 4.1$ (certified value $47.3 \pm 1.6$ ).
2.2.2. Mapping of Pseudo-Total Arsenic Contents. Spatial data analysis was carried out using ArcGIS 10.3 software (ArcGIS Desktop: Release 10, Environmental Systems Research Institute, Redlands, CA). Inverse distance weighting (IDW) was used in this research to interpolate pseudo-total As contents. 


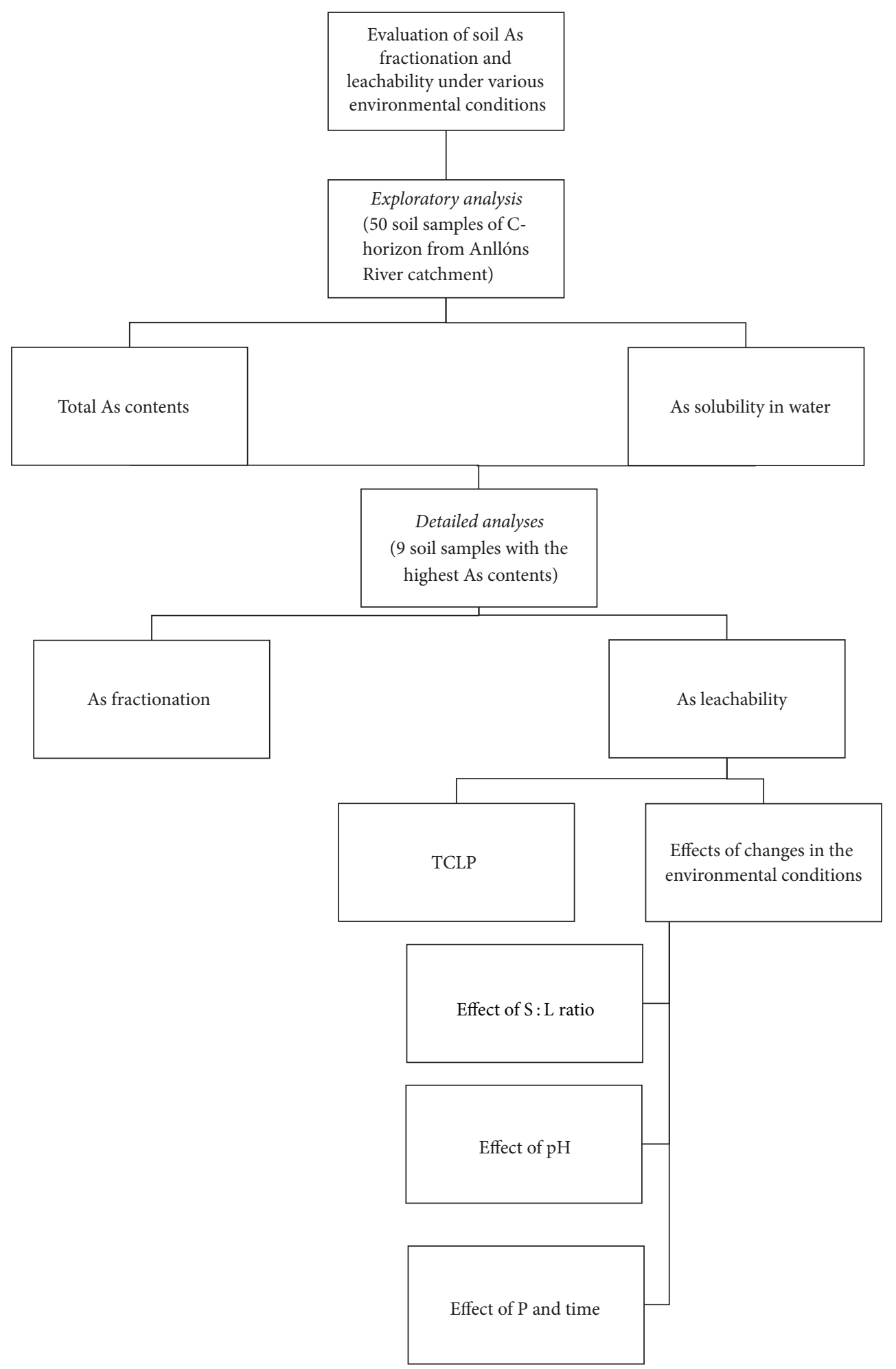

FIGURE 2: Scheme of the experimental procedure.

All interpolation methods were developed based on the theory that points closer to each other have more correlations and similarities than those farther away [39]. IDW is a linear combination of the observed values, inversely weighted by the distances of the observation locations from the interpolation point. This interpolation method is based on the assumption that the influence of a known data point is inversely related to the distance from the unknown location that is being estimated [40].

2.2.3. Arsenic Solubility in Water. The German standard method DIN 38414-S4 [41] for the examination of water, 
waste water, sediments, and sludge by the determination of leachability by water was followed, using Milli-Q water at a $1: 10$ soil : water ratio and $24 \mathrm{~h}$ end-over-end agitation. Subsequently, extracts were filtered through $0.45 \mu \mathrm{m}$ syringe filters (Whatman $^{\mathrm{TM}}$ Puradisc $^{\mathrm{TM}} 25$ polyethersulfone filter devices, General Electric Company, Freiburg, Germany) and frozen $\left(-80^{\circ} \mathrm{C}\right)$ until analysis of pseudo-total As concentrations using Inductively Coupled Plasma Spectrometry (ICP-MS). A Varian 820-MS ICP-MS, equipped with collision reaction interface (CRI) technology to reduce polyatomic interferences, was employed for this purpose (Varian Inc., Palo Alto, $\mathrm{CA})$. Iron concentrations were also determined in the extracts. The detection limits for As and Fe were $3.38 \mathrm{ng} \mathrm{L}^{-1}$ and $85.06 \mathrm{ng} \mathrm{L}^{-1}$, respectively. The certified reference material EnviroMat Drinking Water EP-H-1 (catog. number: 140-025032, SCP Science) was used for quality control.

\subsection{Detailed Analyses of Arsenic Speciation and Leachability.} Nine samples with the highest As contents were selected for a more detailed study of As mobilization by determining As solid fractions using a fractionation sequential procedure and solubility under different experimental conditions. Soil samples were numbered according to their geographical location from left to right and top to bottom.

2.3.1. As Fractionation. The sequential extraction procedure (SEP) described by Lombi et al. [18] was applied using $1 \mathrm{~g}$ of soil and $25 \mathrm{~mL}$ of each extractant. This procedure considers the following "operationally defined" chemical pools: F1: exchangeable $\left(0.05 \mathrm{M}\left(\mathrm{NH}_{4}\right)_{2} \mathrm{SO}_{4}, 1 \mathrm{~h}\right.$ shaking), F2: specifically sorbed ( $0.05 \mathrm{M} \mathrm{NH}_{4} \mathrm{H}_{2} \mathrm{PO}_{4}$, 1 h shaking), F3: associated with organic matter and $\mathrm{Al}\left(0.05 \mathrm{M} \mathrm{NH}_{4} \mathrm{~F} \mathrm{pH} \mathrm{7.0,}\right.$ $1 \mathrm{~h}$ shaking), F4: bound to amorphous Fe oxides $\left(0.2 \mathrm{M} \mathrm{NH}_{4}{ }^{-}\right.$ oxalate buffer $\mathrm{pH} 3.25$, $4 \mathrm{~h}$ shaking in the dark), F5: bound to crystalline Fe oxides $\left(0.2 \mathrm{M} \mathrm{NH}_{4}\right.$-oxalate buffer $+0.1 \mathrm{M}$ ascorbic acid pH 3.25, $30 \mathrm{~min}$ in a water bath at $96^{\circ} \mathrm{C}$ ), and $\mathrm{F} 6$ : residual phase (calculated as the difference between pseudototal As content and the sum of As extracted from steps F1 to F5). The extracts resulting from each phase were centrifuged at 5,000 rpm for $15 \mathrm{~min}$ at room temperature, filtered using $0.45 \mu \mathrm{m}$ Whatman Puradisc 25 polyethersulfone syringe filters, and frozen $\left(-80^{\circ} \mathrm{C}\right)$ until analysis of pseudo-total As concentrations using ICP-MS. All reagents were prepared with deionized Milli-Q water. All experiments were run in triplicate and blanks were run simultaneously. Pseudo-total As content of these specific samples was determined by microwave-assisted acid digestion at $150^{\circ} \mathrm{C}$. To this end, $0.2 \mathrm{~g}$ soil was introduced into Teflon ${ }^{\mathrm{TM}}$ microwave digestion vessels with $10 \mathrm{~mL}$ acid solutions formed by $9 \mathrm{~mL} \mathrm{HNO}_{3 \text { (conc) }}$ and $1 \mathrm{~mL} \mathrm{HF}$ (conc) [33]. After digestion, extracts were made up to $100 \mathrm{~mL}$ with $2.5 \% \mathrm{H}_{3} \mathrm{BO}_{3}$ solution added to "neutralize" the excess HF and complex fluoride (forming tetrafluoroboric acid) in solution, as described by Wilson et al. [42]. This dilution with $\mathrm{H}_{3} \mathrm{BO}_{3}$ solution also makes it possible to maintain the $\mathrm{HNO}_{3}$ concentrations below $10 \%$, as required for ICP-MS measurements. Extracts were filtered using $0.45 \mu \mathrm{m}$ Whatman Puradisc 25 polyethersulfone syringe filters and frozen and pseudo-total As concentrations were measured using ICP-MS.

\subsubsection{Arsenic Leachability}

(1) TCLP. Arsenic mobilization was estimated by applying the Toxicity Characteristic Leaching Procedure (TCLP) standard method, which simulates worst-case leaching conditions of landfill wastes and represents a method to evaluate the potential toxicity of a waste material. The EPA Method 1311 [43] was applied, consisting of $24 \mathrm{~h}$ extraction in Milli-Q water adjusted with acetic acid at $\mathrm{pH} 4.5$, using a 1:20 soil: water ratio. After the extraction step, the suspensions were centrifuged at 2,000 rpm for $15 \mathrm{~min}$ and the extracts were filtered using $0.45 \mu \mathrm{m}$ Whatman Puradisc 25 polyethersulfone syringe filters and frozen until analysis of As concentration using ICP-MS.

(2) Effect of Changes in the Environmental Conditions. The effect on As mobilization of solid : liquid ratio, $\mathrm{pH}$, phosphorous, and time was also evaluated. The effect of solid: liquid ratio on As mobilization was tested in a $24 \mathrm{~h}$ extraction for $1: 10$ and $1: 50$ ratios in Milli-Q water. The effect of $\mathrm{pH}$ was studied at $\mathrm{pH}$ values 3,6 , and 9, using 1:10 solid : liquid ratios and $24 \mathrm{~h}$ end-over-end shaking. The $\mathrm{pH}$ was adjusted with either $1 \mathrm{M} \mathrm{HNO}_{3}$ or $1 \mathrm{M} \mathrm{NaOH}$; a saline background of $0.01 \mathrm{M} \mathrm{NaNO}_{3}$ in Milli-Q water was used to counteract the differences in ionic strength due to the addition of acid or base and to more closely simulate the conditions of the soil solution. The effect of $\mathrm{P}$ (added as $\mathrm{NaH}_{2} \mathrm{PO}_{4}$ ) on As mobilization was evaluated by performing an extraction of $1 \mathrm{~g}$ soil in $10 \mathrm{~mL}$ of $0.01 \mathrm{M}$ P prepared in $0.01 \mathrm{M} \mathrm{NaNO}_{3}$; the suspensions were end-over-end-shaken for 24 and $240 \mathrm{~h}$ to simultaneously evaluate the effect of phosphate and extraction time.

After the extraction steps, all extracts were filtered using Whatman Puradisc 25 polyethersulfone syringe filters and frozen $\left(-80^{\circ} \mathrm{C}\right)$ until analysis of pseudo-total As concentrations using ICP-MS. All experiments were run in triplicate and with the corresponding blanks, at room temperature (20 $\left.\pm 2^{\circ} \mathrm{C}\right)$.

2.4. Statistical Analyses. Arsenic mobilization for the aforementioned environmental conditions was evaluated using either Student's $t$-test analysis or one-way analysis of variance (ANOVA). Single Pearson correlations were calculated to analyse the possible relationships between pseudo-total As content and As mobilized under the different environmental conditions. Principal component analysis (PCA), a multivariate statistical technique widely used as a tool for reducing the number of dimensions, was applied for a comprehensive study of As mobilization in soil samples. Namely, pseudototal As and Fe, As fractionation, and As mobilization under different environmental conditions, as well as Fe mobilization in phases F4 and F5 of As fractionation, were introduced as inputs in the PCA analysis. The SPSS 20.0 statistical package was used for all the statistical analyses 


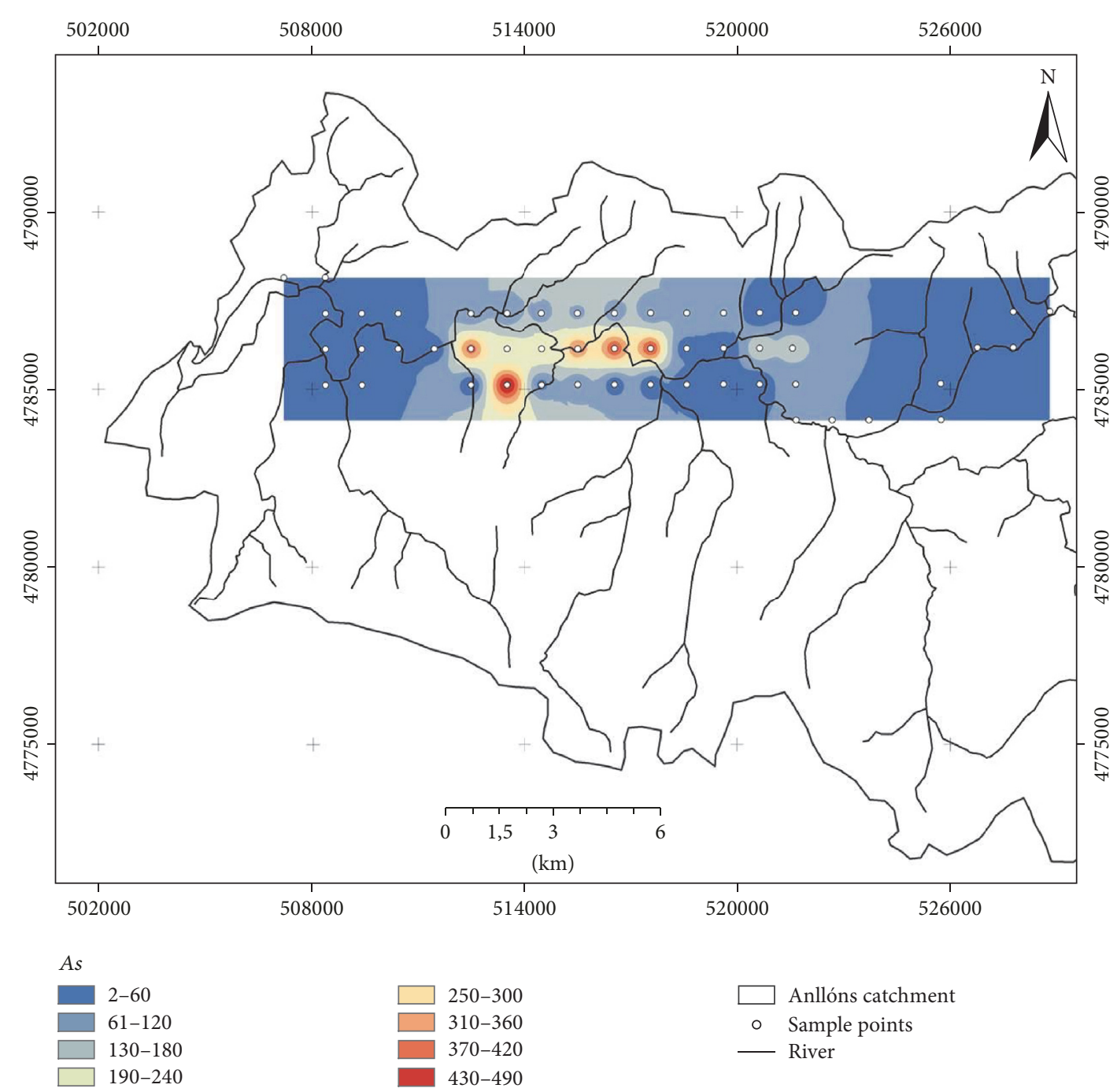

Figure 3: Mapping of pseudo-total As.

(IBM SPSS Statistics for Windows, Version 20.0. Armonk, NY).

\section{Results and Discussion}

3.1. Exploratory Analysis. The spatial distribution of As in the soil samples from the $\mathrm{C}$ horizons is represented in Figure 3. Pseudo-total As concentrations varied between 2 and $489 \mathrm{mg} \mathrm{kg}^{-1}$, with a mean value of $85 \mathrm{mg} \mathrm{kg}^{-1}$. The concentrations were within the range of those detected by Devesa-Rey et al. [31] in polluted sediments of the Anllóns River, which reached a maximum value of $264 \mathrm{mg} \mathrm{kg}^{-1}$.

The statistical distribution of As concentrations can be visually inspected using a box plot (Figure 4(a)). The 25th, 50 th, and 75 th percentiles $\left(14,25\right.$, and $94 \mathrm{mg} \mathrm{kg}^{-1}$, resp.) were represented as lines in vertical boxes, with error bars representing the 10th and 90th percentiles (5 and $344 \mathrm{mg} \mathrm{kg}^{-1}$, resp.). Five soil samples located in the Au-As mineralized area [28] exceeded the 90th percentile and may be considered outliers. The value inferred from the 25 th percentile $\left(14 \mathrm{mg} \mathrm{kg}^{-1}\right)$ can be considered a local background [44], which is slightly lower than the limit allowed for agricultural soils in Galicia, set at 25-30 $\mathrm{mg} \mathrm{kg}^{-1}$ [45], whose upper limit was surpassed by 23 samples. The general reference level for As, fixed at $50 \mathrm{mg} \mathrm{kg}^{-1}$ for soils in the Spanish region of Galicia [46], was exceeded in 21 soil samples (42\%). Concentrations surpassing $50 \mathrm{mg} \mathrm{kg}^{-1}$ are also considered dangerous in several countries and above this threshold soil remediation procedures are recommended [47].

Soluble As concentrations obtained using the German DIN 38414-S4 [41] method ranged between 0.13 and $9.85 \mu \mathrm{g} \mathrm{L}^{-1}$, which are much lower than the acceptable leaching limit values for inert waste landfills determined under similar conditions [48]. Expressed on a dry weight basis, the As extracted ranged between 1.24 and $98.45 \mathrm{ng} \mathrm{kg}^{-1}$, with a mean value of $8.96 \mathrm{ng} \mathrm{kg}^{-1}$. The $25 \mathrm{th}, 50 \mathrm{th}$, and $75 \mathrm{th}$ percentiles corresponded to $1.94,3.88$, and $8.10 \mathrm{ng} \mathrm{kg}^{-1}$, respectively (Figure 4(b)), while the 10th and 90th percentiles corresponded to 1.65 and $20.05 \mathrm{ng} \mathrm{kg}^{-1}$, respectively. Out of five outliers identified for soluble As, only one was also 


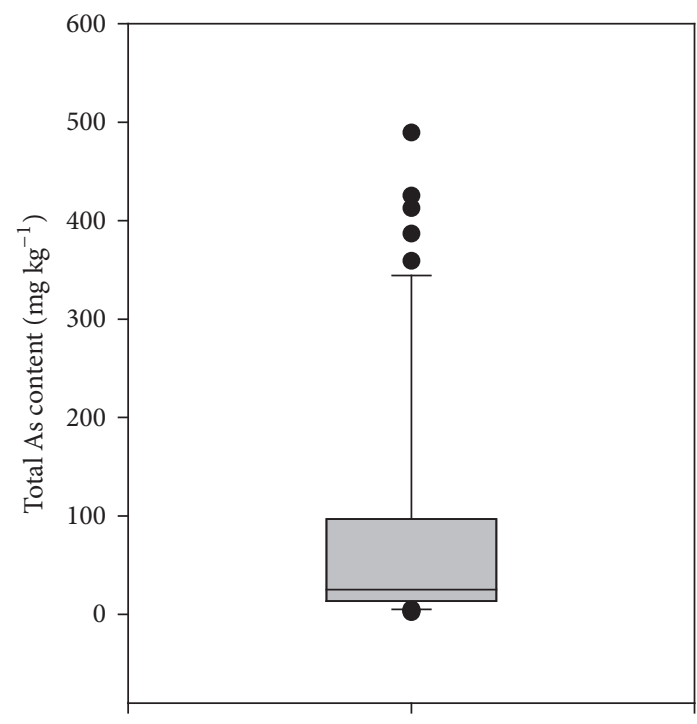

(a)

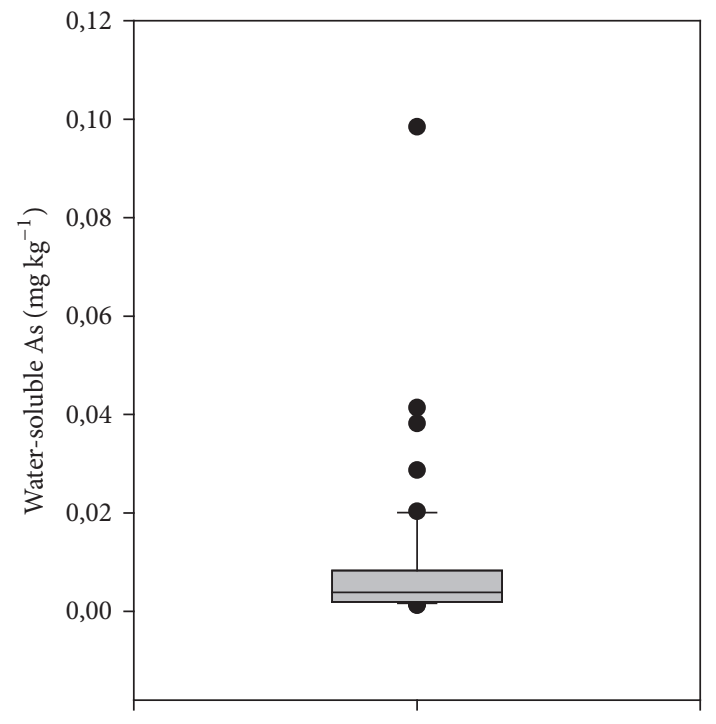

(b)

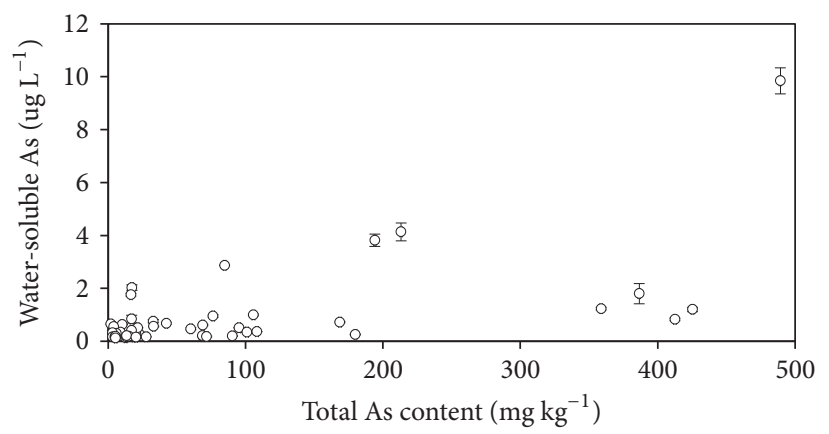

(c)

Figure 4: (a) Box plot for pseudo-total As content. (b) Box plot for water-soluble As. (c) Mobilization of water-soluble As in function of pseudo-total As contents in soil samples. The median and 25th and 75th percentiles were represented as lines in vertical boxes, with error bars representing the 10th and 90th percentiles.

an outlier for pseudo-total As. The percentage of pseudototal As mobilized in these experimental conditions was very low and ranged between 0.002 and $0.03 \%$. No correlation between pseudo-total As and water-soluble As was observed (Figure 4(c)).

\subsection{Detailed Analyses of As Speciation and Leachability. Nine} samples with the highest As contents (108-489 $\mathrm{mg} \mathrm{kg}^{-1}$ ) were submitted to a more detailed study including As fractionation and As leachability in various extractants. In these soil samples, the $\mathrm{pH}$ varied between 5.6 and 7.1 (Table 1), Mn concentration ranged between 0.2 and $3.0 \%$, and pseudo-total $\mathrm{Fe}$ content varied between 1.3 and $6.7 \%$. No correlation was found between pseudo-total As and Fe either in the selected samples or in the exploratory analysis (data not shown). Semiquantitative mineralogical analysis of soil samples using $\mathrm{X}$-ray diffraction did not identify As minerals. Soil organic matter was not determined because this component is scarce in soil C horizons.

3.2.1. As Fractionation. The results of As fractionation following the procedure of Lombi et al. [18] are shown in
Table 1. The following decreasing order of abundance of the fractions was observed: F5 $>$ F4 $\sim$ F6 $>$ F2 $\sim \mathrm{F} 3>$ F1. The predominant fraction was F5, which corresponds to As bound to crystalline $\mathrm{Fe}$ oxides, with percentages varying between 37.4 and $60.7 \%$ with respect to pseudo-total As, followed by F4 (As bound to amorphous Fe oxides), with percentages varying between 15.8 and $39.8 \%$, and F6 (As in the residual phase), with values between 2.1 and $30.7 \%$. Arsenic associated with aluminium and organic matter (F3) accounted for 2.2-6.4\% of pseudo-total As and was similar to specifically sorbed As (F2) (between 2.4 and $5.7 \%$ of pseudototal As). The exchangeable As (F1) was the least abundant fraction, accounting for only $0.01-0.05 \%$ of pseudo-total As. In summary, the results of the fractionation procedure revealed that As was mainly associated with amorphous and crystalline $\mathrm{Fe}$ oxides, which together represent 63 to $86 \%$ of pseudo-total As and justify the low water-soluble As concentrations. Only 2-6\% of pseudo-total As corresponded to $\mathrm{F} 1$ and $\mathrm{F} 2$ fractions that are considered the most mobile [49] and responsible for As toxicity in soils [50].

The As distribution in the soils of the Anllóns Basin was slightly different from that observed in the bed sediments of 
TABLE 1: Soil pH, pseudo-total Fe, Mn, and As content, and As fractionation in soil samples following the SEP procedure described by Lombi et al. (1999).

\begin{tabular}{|c|c|c|c|c|c|c|c|c|c|c|}
\hline Sample & $\mathrm{pH}$ & $\begin{array}{c}\mathrm{Fe}_{\mathrm{XRF}} \\
(\%)\end{array}$ & $\underset{\left(\mathrm{mg} \mathrm{kg}^{-1}\right)}{\mathrm{Mn}_{\mathrm{XRF}}}$ & $\begin{array}{c}\mathrm{As}_{\mathrm{T}, \mathrm{XRF}} \\
\left(\mathrm{mg} \mathrm{kg}^{-1}\right)\end{array}$ & $\begin{array}{c}\mathrm{F} 1 \\
\left(\mathrm{mg} \mathrm{kg}^{-1}\right)\end{array}$ & $\begin{array}{c}\mathrm{F} 2 \\
\left(\mathrm{mg} \mathrm{kg}^{-1}\right)\end{array}$ & $\begin{array}{c}\mathrm{F} 3 \\
\left(\mathrm{mg} \mathrm{kg}^{-1}\right)\end{array}$ & $\begin{array}{c}\mathrm{F} 4 \\
\left(\mathrm{mg} \mathrm{kg}^{-1}\right)\end{array}$ & $\begin{array}{c}\mathrm{F} 5 \\
\left(\mathrm{mg} \mathrm{kg}^{-1}\right)\end{array}$ & $\begin{array}{c}\mathrm{F} 6 \\
\left(\mathrm{mg} \mathrm{kg}^{-1}\right)\end{array}$ \\
\hline 1 & 6.4 & 2.2 & 313 & 489 & $\begin{array}{c}0.13 \\
(0.04 \%)\end{array}$ & $\begin{array}{c}12.19 \\
(3.70 \%)\end{array}$ & $\begin{array}{c}20.87 \\
(6.33 \%)\end{array}$ & $\begin{array}{c}86.28 \\
(26.18 \%)\end{array}$ & $\begin{array}{c}123.37 \\
(37.43 \%)\end{array}$ & $\begin{array}{c}86.71 \\
(26.31 \%)\end{array}$ \\
\hline 2 & 6.6 & 3.5 & 401 & 387 & $\begin{array}{c}0.16 \\
(0.05 \%)\end{array}$ & $\begin{array}{c}13.74 \\
(3.95 \%)\end{array}$ & $\begin{array}{c}10.44 \\
(3.00 \%)\end{array}$ & $\begin{array}{c}75.50 \\
(21.72 \%)\end{array}$ & $\begin{array}{c}184.79 \\
(53.17 \%)\end{array}$ & $\begin{array}{c}62.91 \\
(18.10 \%)\end{array}$ \\
\hline 3 & 7.1 & 4.6 & 533 & 194 & $\begin{array}{c}0.08 \\
(0.04 \%)\end{array}$ & $\begin{array}{c}5.86 \\
(3.49 \%)\end{array}$ & $\begin{array}{c}5.70 \\
(3.39 \%)\end{array}$ & $\begin{array}{c}28.70 \\
(17.08 \%)\end{array}$ & $\begin{array}{c}102.01 \\
(60.71 \%)\end{array}$ & $\begin{array}{c}25.69 \\
(15.29 \%)\end{array}$ \\
\hline 4 & 6.8 & 4.5 & 531 & 213 & $\begin{array}{c}0.07 \\
(0.05 \%)\end{array}$ & $\begin{array}{c}6.21 \\
(3.94 \%)\end{array}$ & $\begin{array}{c}5.42 \\
(3.44 \%)\end{array}$ & $\begin{array}{c}29.33 \\
(18.60 \%)\end{array}$ & $\begin{array}{c}92.83 \\
(58.87 \%)\end{array}$ & $\begin{array}{c}23.82 \\
(15.11 \%)\end{array}$ \\
\hline 5 & 6.3 & 3.0 & 372 & 359 & $\begin{array}{c}0.09 \\
(0.03 \%)\end{array}$ & $\begin{array}{c}8.82 \\
(2.61 \%)\end{array}$ & $\begin{array}{c}9.33 \\
(2.76 \%)\end{array}$ & $\begin{array}{c}56.89 \\
(16.82 \%)\end{array}$ & $\begin{array}{c}168.76 \\
(49.89 \%)\end{array}$ & $\begin{array}{c}94.35 \\
(27.89 \%)\end{array}$ \\
\hline 6 & 6.2 & 3.2 & 324 & 413 & $\begin{array}{c}0.08 \\
(0.02 \%)\end{array}$ & $\begin{array}{c}9.32 \\
(2.44 \%)\end{array}$ & $\begin{array}{c}8.43 \\
(2.21 \%)\end{array}$ & $\begin{array}{c}71.52 \\
(18.76 \%)\end{array}$ & $\begin{array}{c}201.13 \\
(52.75 \%)\end{array}$ & $\begin{array}{c}90.83 \\
(23.82 \%)\end{array}$ \\
\hline 7 & 6.0 & 2.9 & 329 & 425 & $\begin{array}{c}0.08 \\
(0.02 \%)\end{array}$ & $\begin{array}{c}9.53 \\
(2.42 \%)\end{array}$ & $\begin{array}{c}9.61 \\
(2.44 \%)\end{array}$ & $\begin{array}{c}77.11 \\
(19.60 \%)\end{array}$ & $\begin{array}{c}225.82 \\
(57.39 \%)\end{array}$ & $\begin{array}{c}71.31 \\
(18.12 \%)\end{array}$ \\
\hline 8 & 5.6 & 1.3 & 200 & 169 & $\begin{array}{c}0.06 \\
(0.05 \%)\end{array}$ & $\begin{array}{c}7.21 \\
(5.72 \%)\end{array}$ & $\begin{array}{c}8.12 \\
(6.43 \%)\end{array}$ & $\begin{array}{c}50.21 \\
(39.78 \%)\end{array}$ & $\begin{array}{c}57.98 \\
(45.94 \%)\end{array}$ & $\begin{array}{c}2.68 \\
(2.13 \%)\end{array}$ \\
\hline 9 & 6.9 & 6.7 & 2981 & 108 & $\begin{array}{c}0.01 \\
(0.01 \%)\end{array}$ & $\begin{array}{c}3.18 \\
(3.46 \%)\end{array}$ & $\begin{array}{c}2.66 \\
(2.89 \%)\end{array}$ & $\begin{array}{c}14.56 \\
(15.83 \%)\end{array}$ & $\begin{array}{c}43.35 \\
(47.15 \%)\end{array}$ & $\begin{array}{c}28.21 \\
(30.68 \%)\end{array}$ \\
\hline
\end{tabular}

Figures in parentheses in the fractionation analysis indicate percentage of pseudo-total As solubilised in each step.

this river, where the residual phase predominates (up to $75 \%$ of pseudo-total As in some samples), followed by As bound to Fe oxides, representing up to $55 \%$ of pseudo-total 1 As $[31,33]$. However the results of the fractionation are in agreement with those found in vineyard soils by Nóvoa-Muñoz et al. [51], who have observed a predominance of the As fraction associated with crystalline $\mathrm{Al}$ and $\mathrm{Fe}$ oxides; they also agree with those of Moreno-Jiménez et al. [49] who also have found a predominance of As retained by $\mathrm{Al}$ and $\mathrm{Fe}$ hydrous oxides in soils adjacent to an old mine site and with those of Li et al. [25] analysing the speciation of geogenic arsenic in soils.

3.2.2. Arsenic Leachability. The results of the extraction in TCLP showed low concentrations of soluble As ( 0.27 and $1.63 \mu \mathrm{g} \mathrm{L}^{-1}$ ), with the exception of sample 1, for which the As concentration in the extracts reached $41.86 \mu \mathrm{g} \mathrm{L}^{-1}$ (Table 2). These concentrations were much lower than the maximum allowable concentration for TCLP extracts, fixed at $5 \mathrm{mg} \mathrm{L}^{-1}$ by USEPA [52], and also far from $\mathrm{EC}_{20}$ determined by Rubinos et al. [53] for $\mathrm{As}^{\mathrm{V}}$ and $\mathrm{As}{ }^{\mathrm{III}}$ using the Microtox ${ }^{\circledR}$ acute toxicity bioassay (which is usually conducted with TCLP extracts), set at 4.4 and $10.2 \mathrm{mg} \mathrm{L}^{-1}$, respectively.

Expressed in dry weight basis, TCLP-soluble As ranged from 0.01 to $0.03 \mathrm{mg} \mathrm{kg}^{-1}$, which represents 0.006 to $0.012 \%$ of pseudo-total As; sample 1 was an exception, because soluble arsenic reached $0.84 \mathrm{mg} \mathrm{kg}^{-1}$ and represented $0.25 \%$ of pseudo-total As. The low As solubility in the studied soils can be explained by the predominant association of As with Fe oxides that are poorly soluble in the acetic solutions (Table 3) (the highest concentration of solubilized Fe was $5.00 \mathrm{mg} \mathrm{kg}^{-1}$ representing $0.008 \%$ of pseudo-total $\mathrm{Fe}$ ). Arsenic concentrations in TCLP extracts were in the order of those obtained in the DIN 38414-S4 [41] extracts and significant positive Pearson correlations $(p<0.01)$ were found between the two standard methods (Table 4). Nevertheless, none of the methods showed significant positive correlations with pseudo-total arsenic.

For the evaluation of the influence of environmental conditions on As mobilization, the effect of solid : liquid ratio was first investigated in a $24 \mathrm{~h}$ extraction for $1: 10$ and $1: 50$ ratios in Milli-Q water. Arsenic concentrations in the extracts were significantly higher $(p<0.05)$ for the $1: 50 \mathrm{~S}: \mathrm{L}$ ratio than for the $1: 10 \mathrm{~S}: \mathrm{L}$ ratio (Figure 5(a)). Notwithstanding, even for the highest concentration, they were much lower than the leaching limit values established for waste acceptable at landfills, set at $0.05 \mathrm{mg} \mathrm{L}^{-1}$ for inert waste [48]. Expressed on a dry weight basis, As mobilization increased approximately 7 to 29 times with the decrease in S : L ratio (Table 2). Thus, whereas for a 1:10 ratio it varied between $<0.01$ and $0.10 \mathrm{mg} \mathrm{kg}^{-1}(<0.01 \%$ to $0.03 \%$ of pseudo-total As), for a $1: 50$ ratio it ranged between 0.05 and $1.10 \mathrm{mg} \mathrm{kg}^{-1}$ ( 0.05 to $0.33 \%$ of pseudo-total As). Increasing As solubility with increasing liquid: solid ratio was also observed for sediments of the Anllóns River and related to higher risk of As mobilization during resuspension events [33].

For the study of the effect of $\mathrm{pH}$, As solubility in $0.01 \mathrm{M}$ $\mathrm{NaNO}_{3}$ at $\mathrm{pH}$ values 3, 6, and 9 was tested (Table 2). Arsenic leachability increased significantly $(p<0.05)$ with increasing $\mathrm{pH}$ and was 6 to 78 times higher at $\mathrm{pH} 9$ than at $\mathrm{pH} 3$. The maximum percentage of As released, observed at $\mathrm{pH}$ 9, reached $0.71 \%$ of pseudo-total As, whereas the lowest percentage, observed at $\mathrm{pH} 3$, only reached $0.001 \%$. The environmental relevance of the $\mathrm{pH}$ effect on As solubility is revealed in Figure 5(b), where it can be observed that for six soil samples As concentration in the extracts at $\mathrm{pH} 9$ exceeded 
TABLE 2: As leachability in TCLP and the effect of $\mathrm{pH}$, solid : liquid ratio, phosphorous, and time on As mobilization.

\begin{tabular}{|c|c|c|c|c|c|c|c|c|c|}
\hline \multirow[b]{2}{*}{ Sample } & \multirow{2}{*}{$\begin{array}{c}\mathrm{As}_{\mathrm{T}}^{1} \\
\left(\mathrm{mg} \mathrm{kg}^{-1}\right)\end{array}$} & \multirow{2}{*}{$\begin{array}{c}\text { TCLP } \\
\mathrm{As}_{\mathrm{TCLP}} \\
\left(\mathrm{mg} \mathrm{kg}^{-1}\right)\end{array}$} & \multicolumn{2}{|c|}{ Effect of $S$ : L ratio } & \multicolumn{3}{|c|}{ Effect of $\mathrm{pH}$} & \multicolumn{2}{|c|}{ Effect of $\mathrm{P}$ and time } \\
\hline & & & $\begin{array}{c}\mathrm{As}_{1: 10}{ }^{2} \\
\left(\mathrm{mg} \mathrm{kg}^{-1}\right)\end{array}$ & $\begin{array}{c}\mathrm{As}_{1: 50} \\
\left(\mathrm{mg} \mathrm{kg}^{-1}\right)\end{array}$ & $\begin{array}{c}\mathrm{As}_{\mathrm{PH}=3} \\
\left(\mathrm{mg} \mathrm{kg}^{-1}\right)\end{array}$ & $\begin{array}{c}\mathrm{As}_{\mathrm{PH}=6} \\
\left(\mathrm{mg} \mathrm{kg}^{-1}\right)\end{array}$ & $\begin{array}{c}\mathrm{As}_{\mathrm{PH}=9} \\
\left(\mathrm{mg} \mathrm{kg}^{-1}\right)\end{array}$ & $\begin{array}{l}\mathrm{As}_{t=24 \mathrm{~h}} \\
\left(\mathrm{mg} \mathrm{kg}^{-1}\right)\end{array}$ & $\begin{array}{l}\mathrm{As}_{t=240 \mathrm{~h}} \\
\left(\mathrm{mg} \mathrm{kg}^{-1}\right)\end{array}$ \\
\hline 1 & 329.61 & $0.84(0.25 \%)$ & $\begin{array}{c}0.10^{\mathrm{a}} \\
(0.03 \%)\end{array}$ & $\begin{array}{c}1.10^{\mathrm{b}} \\
(0.33 \%)\end{array}$ & $\begin{array}{c}0.12^{\mathrm{a}} \\
(0.04 \%)\end{array}$ & $0.36^{\mathrm{b}}(0.11 \%)$ & $\begin{array}{c}0.73^{\mathrm{c}} \\
(0.22 \%)\end{array}$ & $\begin{array}{c}10.50^{\mathrm{a}} \\
(3.19 \%)\end{array}$ & $\begin{array}{l}17.05^{\mathrm{b}} \\
(5.17 \%)\end{array}$ \\
\hline 2 & 347.53 & $0.03(0.007 \%)$ & $\begin{array}{c}0.02^{\mathrm{a}} \\
(0.005 \%)\end{array}$ & $\begin{array}{c}0.52^{\mathrm{b}} \\
(0.15 \%)\end{array}$ & $\begin{array}{c}0.01^{\mathrm{a}} \\
(0.003 \%)\end{array}$ & $0.10^{\mathrm{b}}(0.03 \%)$ & $\begin{array}{c}0.67^{\mathrm{c}} \\
(0.19 \%)\end{array}$ & $\begin{array}{c}10.97^{\mathrm{a}} \\
(3.16 \%)\end{array}$ & $\begin{array}{c}16.23^{\mathrm{b}} \\
(4.67 \%)\end{array}$ \\
\hline 3 & 168.04 & $0.02(0.01 \%)$ & $\begin{array}{c}0.04^{\mathrm{a}} \\
(0.02 \%)\end{array}$ & $\begin{array}{c}0.26^{\mathrm{b}} \\
(0.16 \%)\end{array}$ & $\begin{array}{c}0.01^{\mathrm{a}} \\
(0.006 \%)\end{array}$ & $0.12^{\mathrm{b}}(0.07 \%)$ & $\begin{array}{c}0.38^{\mathrm{c}} \\
(0.23 \%)\end{array}$ & $\begin{array}{c}3.63^{\mathrm{a}} \\
(2.16 \%)\end{array}$ & $\begin{array}{c}8.48^{\mathrm{b}} \\
(5.05 \%)\end{array}$ \\
\hline 4 & 157.68 & $0.03(0.02 \%)$ & $\begin{array}{c}0.04^{\mathrm{a}} \\
(0.03 \%)\end{array}$ & $\begin{array}{c}0.51^{\mathrm{b}} \\
(0.32 \%)\end{array}$ & $\begin{array}{c}0.02^{\mathrm{a}} \\
(0.01 \%)\end{array}$ & $0.11^{\mathrm{b}}(0.07 \%)$ & $\begin{array}{c}0.38^{\mathrm{c}} \\
(0.24 \%)\end{array}$ & $\begin{array}{c}4.54^{\mathrm{a}} \\
(2.88 \%)\end{array}$ & $\begin{array}{c}7.53^{\mathrm{b}} \\
(4.77 \%)\end{array}$ \\
\hline 5 & 338.24 & $0.03(0.009 \%)$ & $\begin{array}{c}0.01^{\mathrm{a}} \\
(0.004 \%)\end{array}$ & $\begin{array}{c}0.20^{\mathrm{b}} \\
(0.06 \%)\end{array}$ & $\begin{array}{c}0.01^{\mathrm{a}} \\
(0.003 \%)\end{array}$ & $0.11^{\mathrm{b}}(0.03 \%)$ & $\begin{array}{c}0.62^{\mathrm{c}} \\
(0.18 \%)\end{array}$ & $\begin{array}{c}8.13^{\mathrm{a}} \\
(2.40 \%)\end{array}$ & $\begin{array}{l}14.34^{\mathrm{b}} \\
(4.24 \%)\end{array}$ \\
\hline 6 & 381.30 & $0.03(0.009 \%)$ & $\begin{array}{c}0.01^{\mathrm{a}} \\
(0.002 \%)\end{array}$ & $\begin{array}{c}0.12^{\mathrm{b}} \\
(0.03 \%)\end{array}$ & $\begin{array}{c}0.01^{\mathrm{a}} \\
(0.003 \%)\end{array}$ & $0.09^{\mathrm{b}}(0.02 \%)$ & $\begin{array}{c}0.96^{\mathrm{c}} \\
(0.25 \%)\end{array}$ & $\begin{array}{c}8.62^{\mathrm{a}} \\
(2.26 \%)\end{array}$ & $\begin{array}{l}13.38^{\mathrm{b}} \\
(3.51 \%)\end{array}$ \\
\hline 7 & 393.47 & $0.02(0.005 \%)$ & $\begin{array}{c}0.01^{\mathrm{a}} \\
(0.003 \%)\end{array}$ & $\begin{array}{c}0.10^{\mathrm{b}} \\
(0.02 \%)\end{array}$ & $\begin{array}{c}0.01^{\mathrm{a}} \\
(0.003 \%)\end{array}$ & $0.08^{\mathrm{b}}(0.02 \%)$ & $\begin{array}{c}0.49^{\mathrm{c}} \\
(0.13 \%)\end{array}$ & $\begin{array}{c}8.21^{\mathrm{a}} \\
(2.09 \%)\end{array}$ & $\begin{array}{c}14.38^{\mathrm{b}} \\
(3.65 \%)\end{array}$ \\
\hline 8 & 126.21 & $0.02(0.02 \%)$ & $\begin{array}{c}0.01^{\mathrm{a}} \\
(0.006 \%)\end{array}$ & $\begin{array}{c}0.07^{\mathrm{b}} \\
(0.05 \%)\end{array}$ & $\begin{array}{c}0.01^{\mathrm{a}} \\
(0.01 \%)\end{array}$ & $0.18^{\mathrm{b}}(0.14 \%)$ & $\begin{array}{c}0.89^{\mathrm{c}} \\
(0.71 \%)\end{array}$ & $\begin{array}{c}3.75^{\mathrm{a}} \\
(2.97 \%)\end{array}$ & $\begin{array}{c}3.34^{\mathrm{a}} \\
(2.64 \%)\end{array}$ \\
\hline 9 & 91.96 & $0.01(0.006 \%)$ & $\begin{array}{l}3.710^{-3 a} \\
(0.004 \%)\end{array}$ & $\begin{array}{c}0.05^{\mathrm{b}} \\
(0.05 \%)\end{array}$ & $\begin{array}{c}810^{-4 a} \\
(0.001 \%)\end{array}$ & $0.01^{\mathrm{b}}(0.01 \%)$ & $\begin{array}{c}0.05^{\mathrm{c}} \\
(0.06 \%)\end{array}$ & $\begin{array}{c}1.99^{\mathrm{a}} \\
(2.16 \%)\end{array}$ & $\begin{array}{c}2.05^{\mathrm{a}} \\
(2.23 \%)\end{array}$ \\
\hline
\end{tabular}

${ }^{1}$ Pseudo-total As content determined by microwave digestion used for the calculation of the percentages of As extracted; ${ }^{2}$ As extracted using DIN 38414 -S4 [38]; a, b, c superscript letters indicate significant differences $(p<0.05)$ between the tested experimental conditions for each parameter; figures in parentheses indicate the percentage of As mobilized with respect to the pseudo-total As concentrations.

TABLE 3: Fe leachability in TCLP and the effect of $\mathrm{pH}$, solid : liquid ratio, phosphorous, and time on Fe mobilization.

\begin{tabular}{|c|c|c|c|c|c|c|c|c|c|}
\hline \multirow[b]{2}{*}{ Sample } & \multirow[b]{2}{*}{$\mathrm{Fe}_{\mathrm{T}}(\%)$} & \multirow{2}{*}{$\begin{array}{c}\text { TCLP } \\
\mathrm{Fe}_{\mathrm{TCLP}} \\
\left(\mathrm{mg} \mathrm{kg}^{-1}\right)\end{array}$} & \multicolumn{2}{|c|}{ Effect of $S$ : L ratio } & \multicolumn{3}{|c|}{ Effect of $\mathrm{pH}$} & \multicolumn{2}{|c|}{ Effect of $\mathrm{P}$ and time } \\
\hline & & & $\begin{array}{c}\mathrm{Fe}_{1: 10} \\
\left(\mathrm{mg} \mathrm{kg}^{-1}\right)\end{array}$ & $\begin{array}{c}\mathrm{Fe}_{1: 50} \\
\left(\mathrm{mg} \mathrm{kg}^{-1}\right)\end{array}$ & $\begin{array}{c}\mathrm{Fe}_{\mathrm{PH}=3} \\
\left(\mathrm{mg} \mathrm{kg}^{-1}\right)\end{array}$ & $\begin{array}{c}\mathrm{Fe}_{\mathrm{PH}=6} \\
\left(\mathrm{mg} \mathrm{kg}^{-1}\right)\end{array}$ & $\begin{array}{c}\mathrm{Fe}_{\mathrm{PH}=9} \\
\left(\mathrm{mg} \mathrm{kg}^{-1}\right)\end{array}$ & $\begin{array}{c}\mathrm{Fe}_{t=24 \mathrm{~h}} \\
\left(\mathrm{mg} \mathrm{kg}^{-1}\right)\end{array}$ & $\begin{array}{l}\mathrm{Fe}_{t=240 \mathrm{~h}} \\
\left(\mathrm{mg} \mathrm{kg}^{-1}\right)\end{array}$ \\
\hline 1 & 2.90 & $\begin{array}{c}1.73 \\
(0.01 \%)\end{array}$ & $0.02(<0.01 \%)$ & $\begin{array}{c}0.22 \\
(<0.01 \%)\end{array}$ & $\begin{array}{c}1.74 \\
(0.01 \%)\end{array}$ & $\begin{array}{c}0.07 \\
(<0.01 \%)\end{array}$ & $\begin{array}{c}0.56 \\
(<0.01 \%)\end{array}$ & $\begin{array}{c}0.10 \\
(<0.01 \%)\end{array}$ & $\begin{array}{c}0.20 \\
(<0.01 \%)\end{array}$ \\
\hline 2 & 4.97 & $\begin{array}{c}0.40 \\
(<0.01 \%)\end{array}$ & $0.01(<0.01 \%)$ & $\begin{array}{c}1.67 \\
(<0.01 \%)\end{array}$ & $\begin{array}{c}3.96 \\
(0.01 \%)\end{array}$ & $<$ d. l. $^{2}$ & $<{\text { d. } . .^{2}}^{2}$ & $\begin{array}{c}<0.01 \\
(<0.01 \%)\end{array}$ & $\begin{array}{c}0.02 \\
(<0.01 \%)\end{array}$ \\
\hline 3 & 6.19 & $\begin{array}{c}0.77 \\
(<0.01 \%)\end{array}$ & $0.85(<0.01 \%)$ & $\begin{array}{c}0.43 \\
(<0.01 \%)\end{array}$ & $\begin{array}{c}8.34 \\
(0.01 \%)\end{array}$ & $\begin{array}{c}0.04 \\
(<0.01 \%)\end{array}$ & $\begin{array}{c}0.26 \\
(<0.01 \%)\end{array}$ & $\begin{array}{c}0.03 \\
(<0.01 \%)\end{array}$ & $\begin{array}{c}0.07 \\
(<0.01 \%)\end{array}$ \\
\hline 4 & 6.50 & $\begin{array}{c}5.00 \\
(0.01 \%)\end{array}$ & $1.01(<0.01 \%)$ & $\begin{array}{c}0.54 \\
(<0.01 \%)\end{array}$ & $\begin{array}{c}5.67 \\
(0.01 \%)\end{array}$ & $<$ d..$^{2}$ & $\begin{array}{c}1.62 \\
(<0.01 \%)\end{array}$ & $\begin{array}{c}0.03 \\
(<0.01 \%)\end{array}$ & $\begin{array}{c}0.10 \\
(<0.01 \%)\end{array}$ \\
\hline 5 & 4.47 & $\begin{array}{c}0.59 \\
(<0.01 \%)\end{array}$ & $0.06(<0.01 \%)$ & $\begin{array}{c}0.34 \\
(<0.01 \%)\end{array}$ & $\begin{array}{c}1.19 \\
(<0.01 \%)\end{array}$ & $<$ d.1. ${ }^{2}$ & $\begin{array}{c}0.66 \\
(<0.01 \%)\end{array}$ & $\begin{array}{c}0.10 \\
(<0.01 \%)\end{array}$ & $\begin{array}{c}0.10 \\
(<0.01 \%)\end{array}$ \\
\hline 6 & 4.38 & $\begin{array}{c}1.01 \\
(<0.01 \%)\end{array}$ & $<0.01(<0.01 \%)$ & $\begin{array}{c}0.12 \\
(<0.01 \%)\end{array}$ & $\begin{array}{c}2.79 \\
(0.01 \%)\end{array}$ & $<$ d..$^{2}$ & $\begin{array}{c}1.59 \\
(<0.01 \%)\end{array}$ & $\begin{array}{c}0.15 \\
(<0.01 \%)\end{array}$ & $\begin{array}{c}0.08 \\
(<0.01 \%)\end{array}$ \\
\hline 7 & 4.26 & $\begin{array}{c}0.74 \\
(<0.01 \%)\end{array}$ & $0.01(<0.01 \%)$ & $\begin{array}{c}0.09 \\
(<0.01 \%)\end{array}$ & $\begin{array}{c}1.62 \\
(<0.01 \%)\end{array}$ & $<$ d..$^{2}$ & $\begin{array}{c}0.16 \\
(<0.01 \%)\end{array}$ & $\begin{array}{c}0.08 \\
(<0.01 \%)\end{array}$ & $\begin{array}{c}0.10 \\
(<0.01 \%)\end{array}$ \\
\hline 8 & 1.20 & $\begin{array}{c}0.50 \\
(<0.01 \%)\end{array}$ & $0.05(<0.01 \%)$ & $\begin{array}{c}0.17 \\
(<0.01 \%)\end{array}$ & $\begin{array}{c}2.22 \\
(0.02 \%)\end{array}$ & $<{\text { d. } . .^{2}}^{2}$ & $\begin{array}{c}1.63 \\
(0.02 \%)\end{array}$ & $\begin{array}{c}0.43 \\
(<0.01 \%)\end{array}$ & $\begin{array}{c}0.43 \\
(<0.01 \%)\end{array}$ \\
\hline 9 & 6.59 & $<$ d..$^{1}$ & $0.03(<0.01 \%)$ & $\begin{array}{c}0.66 \\
(<0.01 \%)\end{array}$ & $<$ d..$^{2}$ & $<$ d..$^{2}$ & $<$ d. $^{2} .^{2}$ & $\begin{array}{c}0.03 \\
(<0.01 \%)\end{array}$ & $\begin{array}{c}0.05 \\
(<0.01 \%)\end{array}$ \\
\hline
\end{tabular}

${ }^{1}$ d.l.: detection limit of Fe in TCLP method equal to $1.7 \cdot 10^{-3} \mathrm{mg} \mathrm{kg}^{-1} ;{ }^{2}$ d.l.: detection limit of Fe in the study of pH effect equal to $8.5 \cdot 10^{-4} \mathrm{mg} \mathrm{kg}^{-1}$; figures in parentheses indicate the percentage of Fe mobilized with respect to the pseudo-total Fe concentrations.

or was close to the leaching limit value for waste acceptable at landfills for inert waste, set at $0.05 \mathrm{mg} \mathrm{L}^{-1}$ [45]. These results agree with other studies reporting the higher solubility of As at alkaline $\mathrm{pH}$ in soils and sediments $[32,33,54,55]$. Alkaline $\mathrm{pH}$ values favour As mobilization due to the displacement of As by hydroxyl ions competing for sorption sites and the more negative surface charges of active soil components at this $\mathrm{pH}$, which hinder the subsequent adsorption. In cases where higher As mobilization has been observed at acidic $\mathrm{pH}$ in comparison with circumneutral $\mathrm{pH}$ values, it has been 
TABle 4: Significant Pearson correlation coefficients between pseudo-total As and the As mobilized under the different studied conditions.

\begin{tabular}{|c|c|c|c|c|c|c|c|c|c|}
\hline & $\mathrm{As}_{\mathrm{T}}$ & $A s_{\text {DIN }}$ & $\mathrm{As}_{\mathrm{TCLP}}$ & $\mathrm{As}_{\mathrm{pH} 3}$ & $\mathrm{As}_{\mathrm{pH} 6}$ & $\mathrm{As}_{\mathrm{pH} 9}$ & $\mathrm{As}_{1: 50}$ & As- $\mathrm{P}_{t=24 \mathrm{~h}}$ & As $-\mathrm{P}_{t=240 \mathrm{~h}}$ \\
\hline $\mathrm{As}_{\mathrm{T}}$ & 1 & & & & & & & & \\
\hline $\mathrm{As}_{\mathrm{DIN}}$ & 0.096 & 1 & & & & & & & \\
\hline $\mathrm{As}_{\mathrm{TCLP}}$ & 0.237 & $0.895^{* *}$ & 1 & & & & & & \\
\hline $\mathrm{As}_{\mathrm{pH} 3}$ & 0.230 & $0.903^{* *}$ & $0.987^{* *}$ & 1 & & & & & \\
\hline $\mathrm{As}_{\mathrm{pH} 6}$ & 0.163 & $0.828^{* *}$ & $0.873^{* *}$ & $0.902^{* *}$ & 1 & & & & \\
\hline $\mathrm{As}_{\mathrm{pH} 9}$ & 0.467 & 0.074 & 0.194 & 0.213 & 0.412 & 1 & & & \\
\hline $\mathrm{As}_{1: 50}$ & 0.216 & $0.918^{* *}$ & $0.838^{* *}$ & $0.823^{* *}$ & $0.739^{* *}$ & 0.149 & 1 & & \\
\hline As $-\mathrm{P}_{t=24 \mathrm{~h}}$ & $0.896^{* *}$ & 0.318 & 0.445 & 0.437 & 0.375 & $0.504^{*}$ & $0.513^{*}$ & 1 & \\
\hline As- $P_{t=240 \mathrm{~h}}$ & $0.927^{* *}$ & 0.389 & 0.441 & 0.434 & 0.373 & 0.418 & $0.519^{*}$ & $0.943^{* *}$ & 1 \\
\hline
\end{tabular}

The level of significance is indicated: ${ }^{* *} p<0.01 ;{ }^{*} p<0.05$.

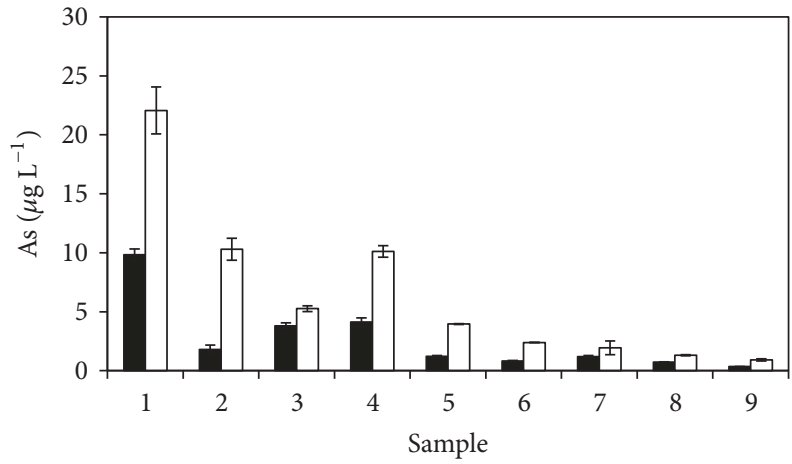

- S:L $1: 10$ $\square$ S:L $1: 50$

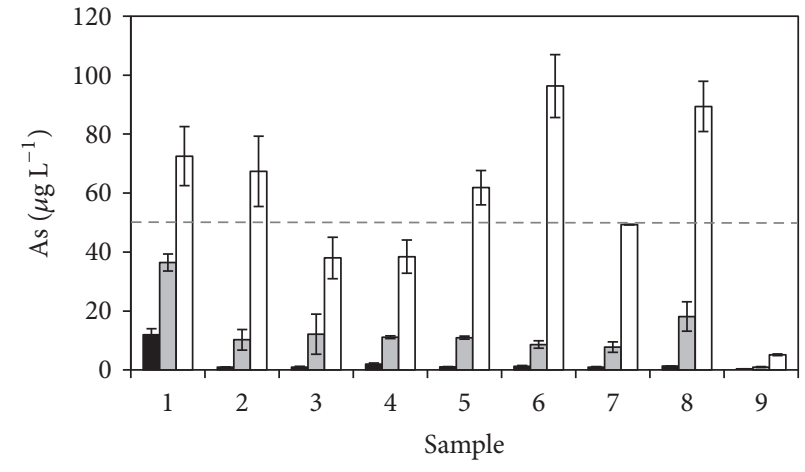

- $\mathrm{pH} 3$

$\square \mathrm{pH} 6$

$\square \mathrm{pH} 9$

(a)

(b)

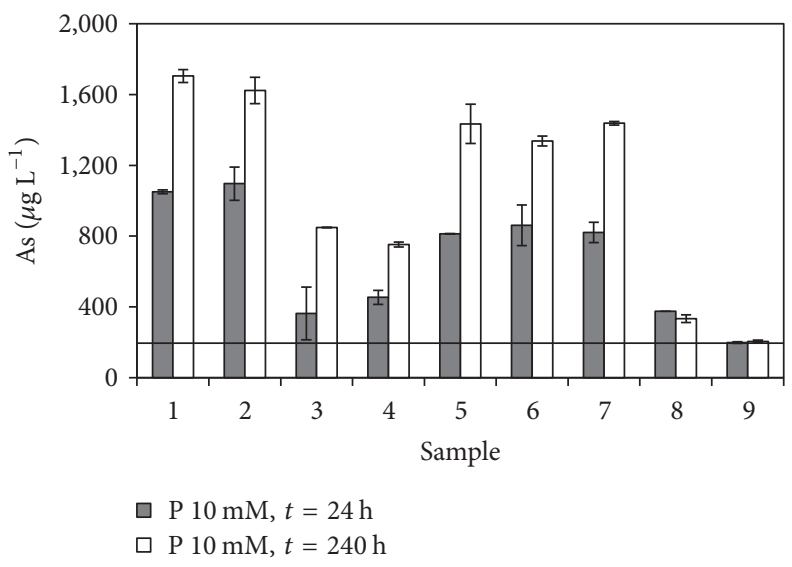

(c)

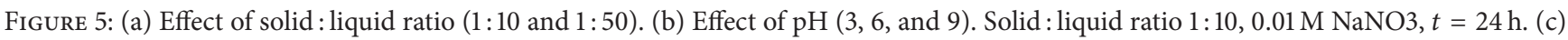
Effect of $\mathrm{P}$ and time (24 and $240 \mathrm{~h}$ ). The grey dashed and the solid black lines indicate the leaching limit values for waste acceptable in landfills for inert and nonhazardous waste, respectively (EC 2003).

attributed to the partial dissolution of As-bearing Fe and $\mathrm{Al}$ (hydr)oxides in soils and sediments $[32,54]$. In this study, although As is mainly associated with Fe oxides, less than $0.02 \%$ of pseudo-total Fe was released at pH 3 (Table 3), which explains why there was no correlation between $\mathrm{Fe}$ and As at this $\mathrm{pH}$.
The effect of phosphorous on As mobilization was tested in the presence of $10 \mathrm{mM} P$ concentration. Arsenic in this extract was the only fraction which showed a linear relationship with pseudo-total soil As content $\left(R^{2}=0.88\right)$. Leached As ranged between 1.99 and $10.97 \mathrm{mg} \mathrm{kg}^{-1}$ (between 2.09 and $3.19 \%$ of pseudo-total As) and was significantly $(p<0.05)$ 
higher ( 100 to 1000 times) than the As mobilized in water using the DIN 38414-S4 method [38]. This favourable effect of phosphate on As mobilization in soils, which has also been observed in sediments of the Anllóns River by Rubinos et al. [33], was attributed to the competition of phosphate and arsenate for sorption sites, because both elements form oxyanions with quasi-identical pKa values and have similar effects on the surface charge of the solids $[56,57]$.

Finally, the effect of time on As mobilization was evaluated in the worst-case scenario analysed in this study, that is, using $10 \mathrm{mM}$ P solutions. The As mobilized at $240 \mathrm{~h}$ varied between 2.05 and $17.05 \mathrm{mg} \mathrm{kg}^{-1}$ (2.64 to $5.17 \%$ of pseudototal As), which implies an increase of approximately 1.7 -fold in As mobilization compared to that obtained at $24 \mathrm{~h}$. The exceptions were samples 8 and 9 (showing the lowest values of pseudo-total As) for which similar results were found at both times.

The environmental relevance of the combined effect of $\mathrm{P}$ and time is reflected in Figure 5(c), where all the samples now exceed the leaching limit value for inert and nonhazardous waste, set at $0.05 \mathrm{mg} \mathrm{L}^{-1}$ and $0.2 \mathrm{mg} \mathrm{L}^{-1}$, respectively, and some of them even approach the leaching limit value for hazardous waste [48]. These findings are noteworthy, especially for aquatic environments that receive inputs of phosphate, because they suggest that As solubility may be underestimated in the short term, such as those frequently used in standard leaching tests and sequential extraction procedures.

It is remarkable that As extracted by the two standard methods (DIN 38414-S4 and TCLP) showed no correlation with pseudo-total As or that mobilized in the most favourable conditions, that is, alkaline $\mathrm{pH}$, presence of phosphate, and long extraction times. This behaviour raises questions about the predictive ability of these standard methods in terms of environmental risk. Although the standard methods provide useful information to compare with leaching limit values and to establish comparisons between researchers from different labs, it becomes evident that other tests must be carried out representing potential scenarios for the assessment of pollutant transfer into aquatic systems.

To examine the relationships between pseudo-total As (and pseudo-total Fe), As fractions (and Fe in steps 4 and 5), and As leachability under diverse experimental conditions, a principal component analysis was applied. Two principal components (PC) with an eigenvalue $>1$ were extracted (Figure 6), which explained $74 \%$ of the total variance. $\mathrm{PCl}$ mainly included the variables corresponding to conditions promoting As mobilization $\left(\mathrm{As}_{\mathrm{pH}=9}, \mathrm{As}-\mathrm{P}_{t=24 \mathrm{~h}}\right.$, and As- $\left.\mathrm{P}_{t=240 \mathrm{~h}}\right)$, plus pseudo-total As and all the As fractions except F3 (As associated with $\mathrm{Al}$ and organic matter). In turn, $\mathrm{PC} 2$ included the variables related to lower As mobilization $\left(\mathrm{As}_{\mathrm{DIN}}, \mathrm{As}_{\mathrm{TCLP}}\right.$, $\mathrm{As}_{1: 50}, \mathrm{As}_{\mathrm{pH}=3}$, and $\left.\mathrm{As}_{\mathrm{pH}=6}\right)$. Pseudo-total $\mathrm{Fe}$ content and $\mathrm{Fe}$ solubilized in steps F4 and F5 of the As fractionation (iron oxides) were not correlated and are not grouped with the As related variables. A possible explanation for this lack of association of As and $\mathrm{Fe}$ is that As mineralizations in this catchment are associated with acid quarzitic veins, which are poor in Fe-rich minerals. Nevertheless, this behaviour is not opposed to the observation that, in the analysed soil samples,

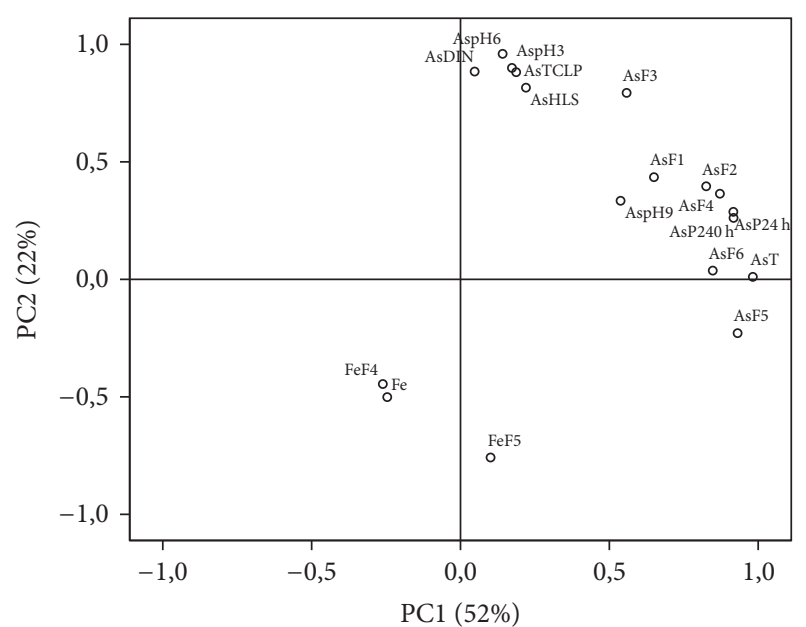

FIGURE 6: Principal component analysis for the evaluation of factors affecting As mobilization.

As is mainly linked to Fe oxides because once weathering, a process typical of $\mathrm{C}$ horizons, releases As from As-bearing primary minerals (mainly arsenopyrite), it shows a great affinity for Fe oxides, to which it is bound by adsorption and coprecipitation [56].

3.3. General Overview. Arsenic transfer from soils to surface and subsurface waters may constitute an important risk to aquatic life and human health [17]. The results of this study highlight the presence of high but variable concentrations of As in soil samples taken from C horizons in the Anllóns River catchment. The highest As contents were mainly found in or close to the As-Au mineralization area, as well as in the proximity of the river, thus aggravating the transfer risk to the fluvial ecosystem.

Chemical fractionation of arsenic indicated a low potential mobilization in these soil samples as the sum of F1 and F2, considered the most mobile fractions, only represented $6 \%$ of the pseudo-total As at most. In fact, the mobilization of As estimated by the standard procedures DIN 38414-S4 and TCLP was very low (maximum of $0.03 \%$ and $0.25 \%$ of pseudo-total As, resp.).

Nevertheless, the results of this study indicated that changes in environmental conditions, such as modifications in $\mathrm{S}: \mathrm{L}$ ratios, $\mathrm{pH}$ conditions, the presence of competitive anions (phosphate), and contact time, drastically affect As mobilization, increasing As solubility up to 1,600 times. In nature, changes in S:L ratios may occur due to variations in the volume of water percolating the soil in situ. Furthermore, if eroded soil particles reach the river course, $S: L$ ratios may change depending on whether the particles are deposited on the riverbed or maintained in suspension and, in this case, $S: L$ ratios may change with the river flow rate. Moreover, in areas affected by mining activities, soil may be removed in the preparatory step for mining operations and accumulated in spoil heaps subject to leaching, or deposited in dumps where $S: L$ ratios are also affected by the density of the tailings. Contact times that exceed $24 \mathrm{~h}$, which is the time established in 
standard leaching methods, could occur in real conditions during the leaching of soils in situ or dumped as mine spoils and also during transportation as suspended particles along the river course or once they are deposited as bed sediments.

Alkaline conditions can occur as a consequence of contaminant discharges over the soil in situ, or if the materials were dumped in mine tailings, due to mining operations using alkaline solutions for metal beneficiation, such as what occurs where cyanide is used to extract gold. Phosphate concentrations in soil solution may be increased due to fertilization; also, if As-rich soil particles reach the river course, they can interact with soluble phosphate coming from urban and industrial sewage treatment plants and from fertilizers leached or eroded from agricultural soils in the river catchment. In fact, this may be a problem in cases such as in the Anllóns River, where diffuse and point sources of $P$ pollution have been identified along the river course, which result in soluble $\mathrm{P}$ concentrations of up to $1.4 \mathrm{mg} \mathrm{L}^{-1}$ [58]. In the riverbed sediments, high As concentrations have also been detected in many places coinciding with $\mathrm{P}$ concentrations of up to $2324 \mathrm{mg} \mathrm{kg}^{-1}$ [43], thus aggravating the risk of As mobilization.

Overall, this study indicates that although standard leaching methods provide useful information in terms of legal limits or comparable data between laboratories, they can underestimate As mobilization under possible scenarios, such as those occurring in soils affected by contaminant spillages or mining activities. The effect of such environmental conditions which may affect As solubility should be taken into account for a more comprehensive evaluation of the environmental risk caused by As mobilization to aqueous systems.

\section{Conclusions}

Pseudo-total As concentrations (ranging between 2 and $489 \mathrm{mg} \mathrm{kg}^{-1}$ ) up to 8 times higher than the regional generic reference level are found in the $\mathrm{C}$ horizon of soils from the Anllóns River catchment. Arsenic has low solubility in the standard leaching tests DIN 38414-S4 and TCLP (up to a maximum of $0.25 \%$ of pseudo-total As), which is related to the predominance of low mobilization As fractions, as in these soils it is mainly associated with crystalline Fe oxides. Based on this behaviour, the transfer risk of these high As concentrations to groundwater and superficial waters may be considered low. Nevertheless, it is shown that changes in environmental conditions, such as $\mathrm{S}: \mathrm{L}$ ratios, $\mathrm{pH}$ conditions, presence of phosphate, and longer contact time, bring about an increase in As mobilization which can reach up to $5 \%$ of pseudo-total As for the extraction with $10 \mathrm{mM}$ phosphate and $240 \mathrm{~h}$ of contact time. The results of this study indicate that the information provided by the standard methods DIN 38414-S4 and Toxicity Characteristic Leaching Procedure (TCLP) may be considered conservative for a reliable evaluation of the risk of As transfer from soils to water bodies.

Overall, the mobilization studies indicate that the assessment of arsenic leachability based solely on short-term aqueous leaching trials without $\mathrm{pH}$ control underestimates the actual mobilization of arsenic and that $\mathrm{pH}$, solid: liquid ratio, contact time, and the presence of phosphate should be taken into account for the evaluation of the transfer risk of lithogenic arsenic towards aquatic ecosystems and living beings.

\section{Conflicts of Interest}

The authors declare that they have no conflicts of interest.

\section{Acknowledgments}

The authors wish to thank the Spanish Ministry of Economy and Competitiveness (MINECO-FEDER) for financial support (Project Ref. CGL2013-46003-P). Diego MartiñáPrieto wishes to acknowledge the financial support of the Spanish Ministry of Economy and Competitiveness for his FPI Fellowship (BES-2011-044514). Javier Cancelo-González wishes to acknowledge the financial support of the program "Axudas de Consolidación e Estructuración de Unidades de Investigación Competitivas", reference no. GRC2014/028 (Xunta de Galicia).

\section{References}

[1] P. L. Smedley and D. G. Kinniburgh, "A review of the source, behaviour and distribution of arsenic in natural waters," Applied Geochemistry, vol. 17, no. 5, pp. 517-568, 2002.

[2] National Research Council (NRC) and Assembly of Life Sciences (U.S.), "Committee on Medical and Biologic Effects of Environmental Pollutants," in Arsenic: Medical and biological effects of environmental pollutants, National Academy of Sciences, Washington, D.C., USA, 1977.

[3] K. H. Wedepohl, "The composition of the continental crust," Geochimica et Cosmochimica Acta, vol. 59, no. 7, pp. 1217-1232, 1995.

[4] V. Straskraba and R. E. Moran, "Environmental occurrence and impacts of arsenic at gold mining sites in the western United States," International Journal of Mine Water, vol. 9, no. 1-4, pp. 181-191, 1990.

[5] P. L. Smedley, W. M. Edmunds, and K. B. Pelig-Ba, "Mobility of arsenic in groundwater in the obuasi gold-mining area of ghana: some implications for human health," Geological Society, London, Special Publications, vol. 113, pp. 163-181, 1996.

[6] R. Eisler, Biogeochemical, Health, and Ecotoxicological Perspectives on Gold and Gold Mining, CRC Press, 2004.

[7] R. Eisler, "Arsenic hazards to humans, plants, and animals from gold mining," Reviews of Environmental Contamination and Toxicology, vol. 180, pp. 133-165, 2004.

[8] A. N. Flores and L. M. D. Rubio, "Arsenic and metal mobility from au mine tailings in rodalquilar (Almería, SE Spain)," Environmental Earth Sciences, vol. 60, no. 1, pp. 121-138, 2010.

[9] L. Meunier, S. R. Walker, J. Wragg et al., "Effects of soil composition and mineralogy on the bioaccessibility of arsenic from tailings and soil in gold mine districts of nova scotia," Environmental Science \& Technology, vol. 44, no. 7, pp. 26672674, 2010.

[10] L. Meunier, I. Koch, and K. J. Reimer, "Effect of particle size on arsenic bioaccessibility in gold mine tailings of nova scotia," 
Science of the Total Environment, vol. 409, no. 11, pp. 2233-2243, 2011.

[11] V. González, I. García, F. del Moral, S. de Haro, J. A. Sánchez, and M. Simón, "Spreading of pollutants from alkaline mine drainage. Rodalquilar mining district (SE Spain)," Journal of Environmental Management, vol. 106, pp. 69-74, 2012.

[12] M. A. Acheampong, K. Paksirajan, and P. N. L. Lens, "Assessment of the effluent quality from a gold mining industry in Ghana," Environmental Science and Pollution Research, vol. 20, no. 6, pp. 3799-3811, 2013.

[13] R. Toujaguez, F. B. Ono, V. Martins et al., "Arsenic bioaccessibility in gold mine tailings of Delita, Cuba," Journal of Hazardous Materials, vol. 262, pp. 1004-1013, 2013.

[14] S. Fendorf, H. A. Michael, and A. van Geen, "Spatial and temporal variations of groundwater arsenic in south and southeast Asia," Science, vol. 328, no. 5982, pp. 1123-1127, 2010.

[15] J. C. Ng, J. Wang, and A. Shraim, "A global health problem caused by arsenic from natural sources," Chemosphere, vol. 52, no. 9, pp. 1353-1359, 2003.

[16] A. A. Duker, E. J. M. Carranza, and M. Hale, "Arsenic geochemistry and health," Environment International, vol. 31, no. 5, pp. 631-641, 2005.

[17] S. Fendorf, M. J. Herbel, K. J. Tufano, and B. D. Kocar, "Biogeochemical processes controlling the cycling of arsenic in soils and sediments," in Biophysico-Chemical Processes of Heavy Metals and Metalloids in Soil Environments, pp. 313-338, Wiley, NJ, USA, 2007.

[18] E. Lombi, W. W. Wenzel, and R. S. Sletten, "Arsenic adsorption by soils and iron-oxide-coated sand: kinetics and reversibility," Journal of Plant Nutrition and Soil Science, vol. 162, no. 4, pp. 451-456, 1999.

[19] W. W. Wenzel, N. Kirchbaumer, T. Prohaska, G. Stingeder, E. Lombi, and D. C. Adriano, "Arsenic fractionation in soils using an improved sequential extraction procedure," Analytica Chimica Acta, vol. 436, no. 2, pp. 309-323, 2001.

[20] J. Hlavay, T. Prohaska, M. Weisz, W. W. Wenzel, and G. J. Stingeder, "Determination of trace elements bound to soils and sediment fractions: (IUPAC Technical Report)," Pure and Applied Chemistry, vol. 76, no. 2, pp. 415-442, 2004.

[21] W. Hartley, R. Edwards, and N. W. Lepp, "Arsenic and heavy metal mobility in iron oxide-amended contaminated soils as evaluated by short- and long-term leaching tests," Environmental Pollution, vol. 131, no. 3, pp. 495-504, 2004.

[22] H. B. Nicolli, J. Bundschuh, M. D. C. Blanco et al., "Arsenic and associated trace-elements in groundwater from the chacopampean plain, Argentina: Results from 100years of research," Science of the Total Environment, vol. 429, pp. 36-56, 2012.

[23] G. Bianchini, D. Di Giuseppe, and L. V. Antisari, "Soil-water interaction in soils of the Po River Plain (Ferrara, northern Italy): insights on heavy-metal mobility and phytoavailability," Periodico di Mineralogia, vol. 82, no. 1, pp. 163-176, 2013.

[24] T. Kandakji, T. K. Udeigwe, R. Dixon, and L. Li, "Groundwaterinduced alterations in elemental concentration and interactions in semi-arid soils of the southern high plains, USA," Environmental Modeling \& Assessment, vol. 187, no. 11, article no. 665, 2015.

[25] J.-S. Li, J. Beiyuan, D. C. W. Tsang et al., "Arsenic-containing soil from geogenic source in Hong Kong: leaching characteristics and stabilization/solidification," Chemosphere, vol. 182, pp. 3139, 2017.
[26] J. Li, T. Cosugi, S. Riya, A. Terada, and M. Hosomi, "Arsenic leaching potential from excavated rock: sequential leaching test (slt) and rapid small-scale column test (rssct) - a case study," in Arsenic Research and Global Sustainability, P. Bhattacharya, M. Vahter, J. Jarsjö, M. E. Donselaar, J. Bundschuh, and R. Naidu, Eds., Arsenic in the Environment - Proceedings, pp. 157-159, CRC Press, 2016.

[27] P. X. Pinto and S. R. Al-Abed, "Assessing metal mobilization from industrially lead-contaminated soils located at an urban site," Applied Geochemistry, vol. 83, pp. 31-40, 2017.

[28] I. Vázquez, F. Armijo, I. Corvillo, and F. Maraver, "Compuestos emergentes en aguas en línea con la innovación tecnológica," Boletin Sociedad Española Hidrologia Medica, vol. 31, no. S1, pp. 65-66, 2016.

[29] World Reference Base For Soil Resources (WRB), "International soil classification system for naming soils and creating legends for soil maps," in World Soil Resources Reports 106, FAO, Rome, Italy, 2015.

[30] J. Nespereira, "Síntesis sobre los yacimientos auríferos gallegos," in Braña, Revista da Sociedade Galega de Historia Natural: Santiago de Compostela, pp. 18-49, 1978.

[31] R. Devesa-Rey, R. Paradelo, F. Díaz-Fierros, and M. T. Barral, "Fractionation and bioavailability of arsenic in the bed sediments of the Anllóns river (NW Spain)," Water, Air, \& Soil Pollution, vol. 195, no. 1-4, pp. 189-199, 2008.

[32] D. Rubinos, L. Iglesias, R. Devesa-Rey, F. Díaz-Fierros, and M. T. Barral, "Arsenic release from river sediments in a goldmining area (Anllóns river basin, Spain): effect of time, $\mathrm{pH}$ and phosphorous concentration," European Journal of Mineralogy, vol. 22, no. 5, pp. 665-678, 2010.

[33] D. A. Rubinos, L. Iglesias, F. Díaz-Fierros, and M. T. Barral, "Interacting effect of $\mathrm{pH}$, phosphate and time on the release of arsenic from polluted river sediments (Anllóns river, Spain)," Aquatic Geochemistry, vol. 17, no. 3, pp. 281-306, 2011.

[34] R. Devesa-Rey, A. B. Moldes, F. Díaz-Fierros, and M. T. Barral, "Toxicity of Anllóns River sediment extracts using microtox and the zucconi phytotoxicity test," Bulletin of Environmental Contamination and Toxicology, vol. 80, no. 3, pp. 225-230, 2008.

[35] R. Devesa-Rey, F. Díaz-Fierros, and M. T. Barral, "Assessment of enrichment factors and grain size influence on the metal distribution in riverbed sediments (Anllóns river, NW Spain)," Environmental Modeling \& Assessment, vol. 179, no. 1-4, pp. 371388, 2011.

[36] Guidelines for drinking water quality, World Health Organization (WHO), Geneva, Switzerland, 2nd edition, 1993.

[37] M. Costas, R. Prego, A. V. Filgueiras, and C. Bendicho, "Landocean contributions of arsenic through a river-estuary-ria system (SW Europe) under the influence of arsenopyrite deposits in the fluvial basin," Science of the Total Environment, vol. 412413, pp. 304-314, 2011.

[38] F. Guitián Ojea, "Geochemical atlas of galicia (Atlas geoquímico de galicia)," in Dirección Xeral de Industria. Consellería de Industria e Comercio, Xunta de Galicia, Santiago de Compostela, 1992.

[39] J. Yasrebi, M. Saffari, H. Fathi, N. Karimian, M. Moazallahi, and R. Gazni, "Evaluation and comparison of ordinary kriging and inverse distance weighting methods for prediction of spatial variability of some soil chemical parameters," Research Journal of Biological Science, vol. 4, p. 93, 2009.

[40] D. P. Kalivas, V. J. Kollias, and E. H. Apostolidis, "Evaluation of three spatial interpolation methods to estimate forest volume in the municipal forest of the Greek island Skyros," Geo-Spatial Information Science, vol. 16, no. 2, pp. 100-112, 2013. 
[41] "Determination of the leachability by water; German standards methods for the estimation of water, wastewater and sludge: sludge and sediments (Group S) (Eds Fachgruppe Wasserchemie in der GDCh, normausschuss wasserwesen im DIN)," in German Standards Procedure DIN 38414 part 4, 1984.

[42] M. A. Wilson, R. Burt, and C. W. Lee, "Improved elemental recoveries in soils with heating boric acid following microwave total digestion," Communications in Soil Science and Plant Analysis, vol. 37, no. 3-4, pp. 513-524, 2006.

[43] Method 1311: Toxicity Characteristic Leaching Procedure (TCLP), US Environmental Protection Agency, Washington, D.C., USA, 1992.

[44] R. Devesa-Rey, M. L. Iglesias, F. Díaz-Fierros, and M. T. Barral, "Total phosphorous distribution and bioavailability in the bed sediments of an atlantic basin (Galicia, Nw Spain): Spatial distribution and vertical profiles," Water, Air, \& Soil Pollution, vol. 200, no. 1-4, pp. 341-352, 2009.

[45] Consellería de Industria y Comercio-Xunta de Galicia, Estudio sobre la actualización del inventario de suelos contaminados, jerarquización y desarrollo de una legislación para la protección del suelo en Galicia (Study on updating the inventory of contaminated soils, prioritization and development of legislation for soil protection in Galicia), 1996, http://www.xunta.gal/dog/ Publicados/1996/19960828/AnuncioDFEA_es.html.

[46] F. Macías Vázquez and R. Calvo de Anta, "Niveles genéricos de referencia de metales pesados y otros elementos traza en suelos de Galicia," in Eds Consellería de Medio Ambiente e Desenvolvemento Sostible -Xunta de Galicia, p. 229, La Ibérica, Santiago de Compostela, Spain, 2009.

[47] D. C. Adriano, Trace Elements in Terrestrial Enviroments: Biogeochemistry, Bioavailability and Risks of Metals, New York, NY, USA, Springer, 2 edition, 2001.

[48] European Community, Council decision of 19 December 2002, establishing criteria and procedures for the acceptance of waste at landfills pursuant to Article 16 of and Annex II to Directive 1999/31/EC, 2003/33/EC, Brussels, Belgium, 2003.

[49] E. Moreno-Jiménez, R. Manzano, E. Esteban, and J. Peñalosa, "The fate of arsenic in soils adjacent to an old mine site (Bustarviejo, Spain): Mobility and transfer to native flora," Journal of Soils and Sediments, vol. 10, no. 2, pp. 301-312, 2010.

[50] A. Brandstetter, E. Lombi, and W. W. Wenzel, ArsenicContaminated soils: I. Risk Assessment: Remediation of Hazardous Waste Contaminated Soils, D. L. Wise, D. J. Trantolo, H. I. Inyang, and E. D. Cichon, Eds., Marcel Dekker Inc, NY, USA, 2 edition, 2000.

[51] J. C. Nóvoa-Muñoz, J. M. G. Queijeiro, D. Blanco-Ward, C. Álvarez-Olleros, E. García-Rodeja, and A. Martínez-Cortizas, "Arsenic fractionation in agricultural acid soils from NW Spain using a sequential extraction procedure," Science of the Total Environment, vol. 378, no. 1-2, pp. 18-22, 2007.

[52] US Environmental Protection Agency (US EPA), Federal Register, 40CFR, Part 261. 1996, Washington D.C., USA.

[53] D. A. Rubinos, V. Calvo, L. Iglesias, and M. T. Barral, "Acute toxicity of arsenic to aliivibrio fischeri (Microtox ${ }^{\circledR}$ bioassay) as influenced by potential competitive-protective agents," Environmental Science and Pollution Research, vol. 21, no. 14, pp. 86318644, 2014.

[54] S. Van Herreweghe, R. Swennen, V. Cappuyns, and C. Vandecasteele, "Chemical associations of heavy metals and metalloids in contaminated soils near former ore treatment plants: a differentiated approach with emphasis on pHstat-leaching,"
Journal of Geochemical Exploration, vol. 76, no. 2, pp. 113-138, 2002.

[55] T. Lager, K. Hamer, and H. D. Schulz, "Mobility of heavy metals in harbour sediments: an environmental aspect for the reuse of contaminated dredged sediments," Environmental Geology, vol. 48, no. 1, pp. 92-100, 2005.

[56] B. A. Manning and S. Goldberg, "Modeling competitive adsorption of arsenate with phosphate and molybdate on oxide minerals," Soil Science Society of America Journal, vol. 60, no. 1, pp. 121-131, 1996.

[57] Z. Hongshao and R. Stanforth, "Competitive adsorption of phosphate and arsenate on goethite," Environmental Science \& Technology, vol. 35, no. 24, pp. 4753-4757, 2001.

[58] M. E. Rial, Investigación dos procesos que regulan o caudal e a calidade das augas na bacía do Río Anllóns, PhD Dissertation, Universiversidade de Santiago de Compostela, Santiago de Compostela, Spain, 2007. 

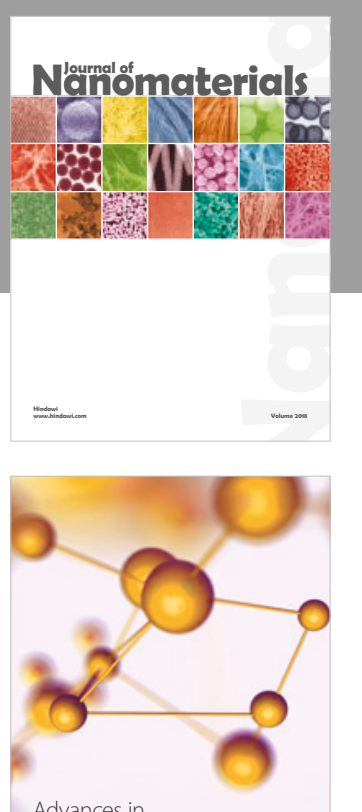

Physical Chemistry
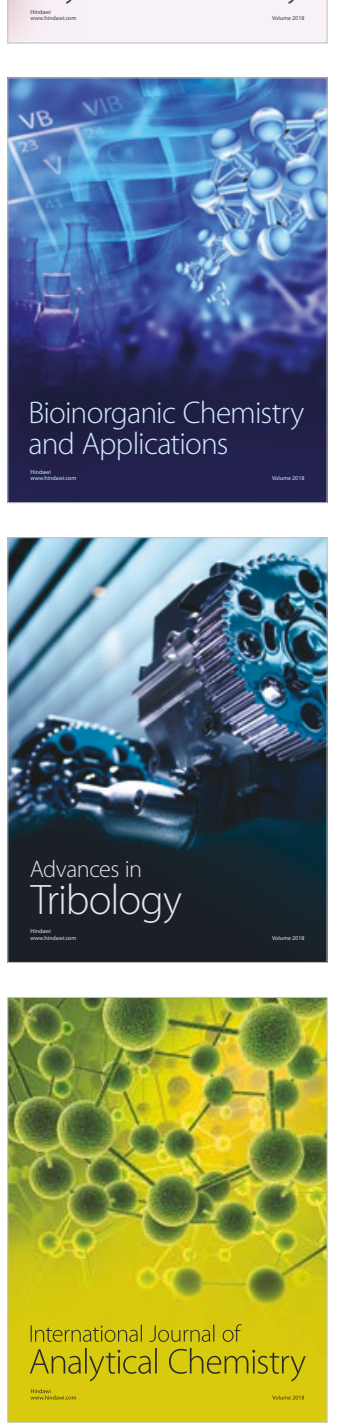

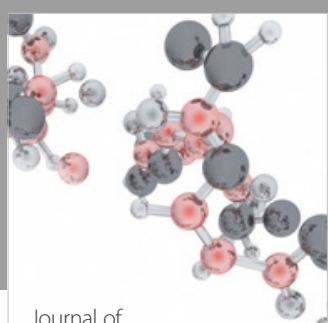

Analytical Methods

in Chemistry

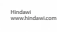

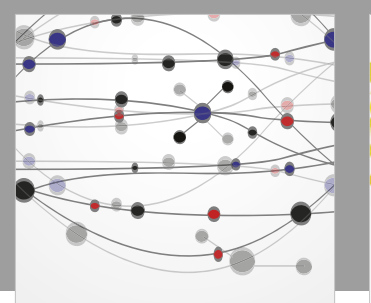

The Scientific World Journal

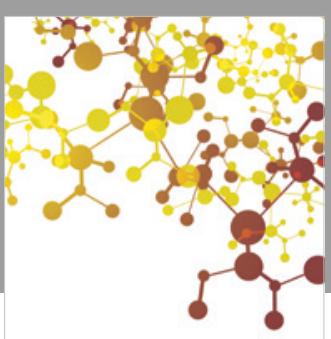

Journal of

Applied Chemistry
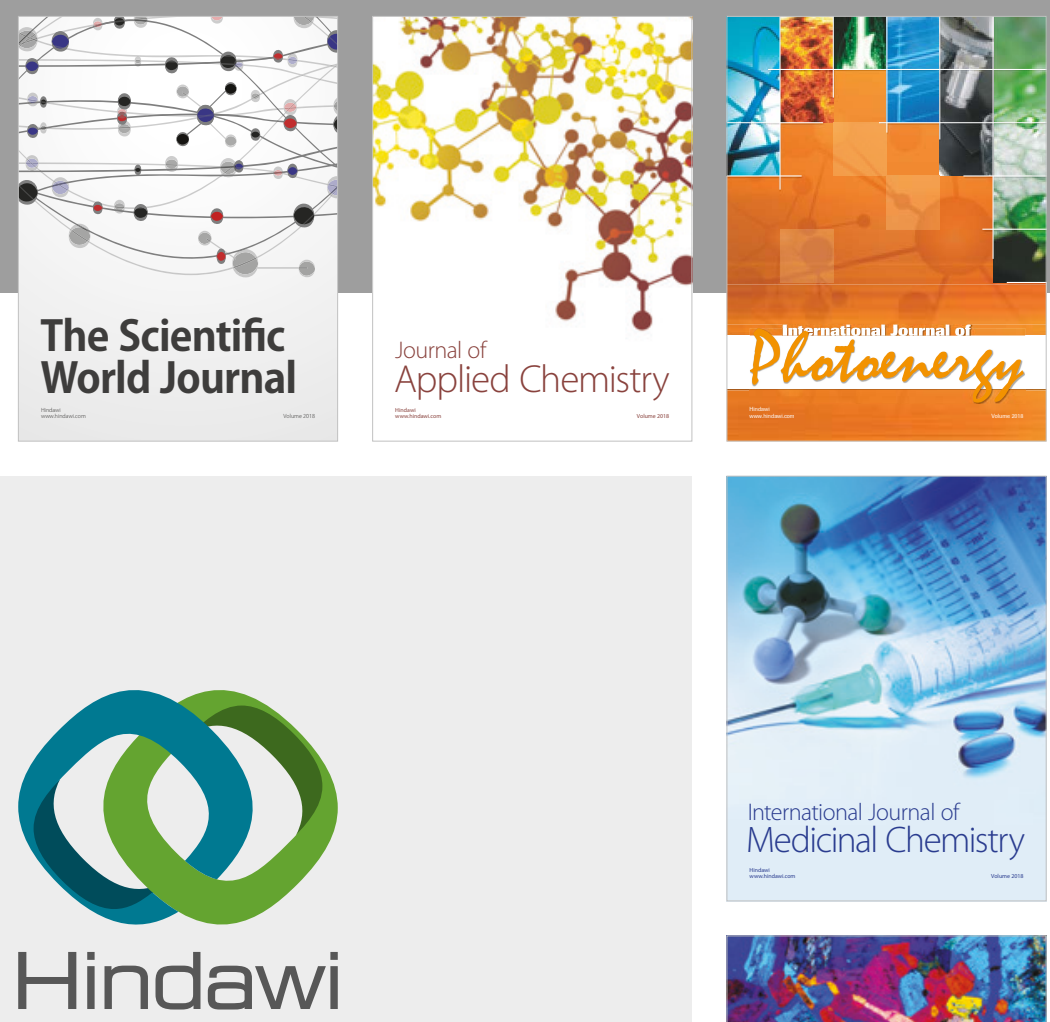

Submit your manuscripts at

www.hindawi.com
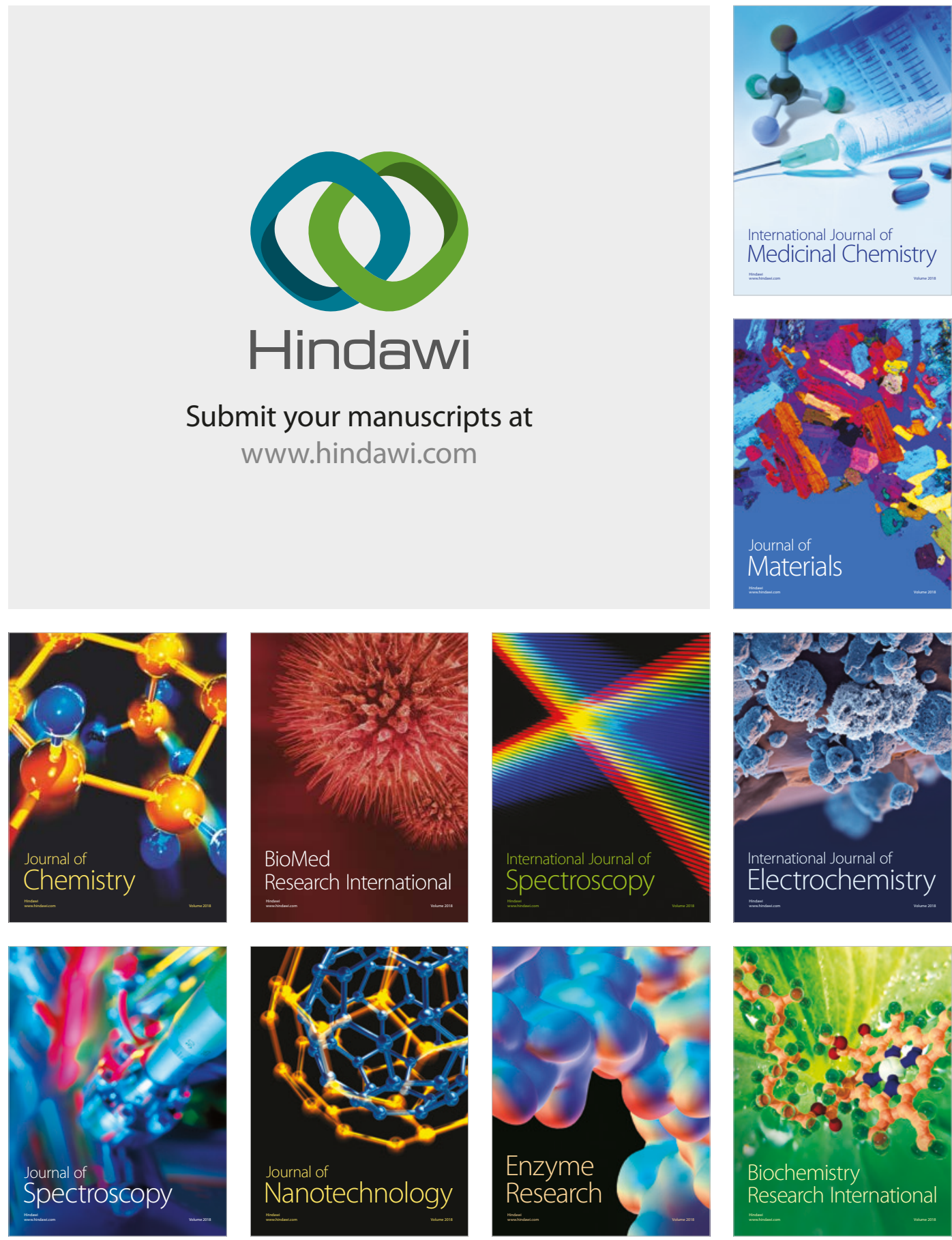
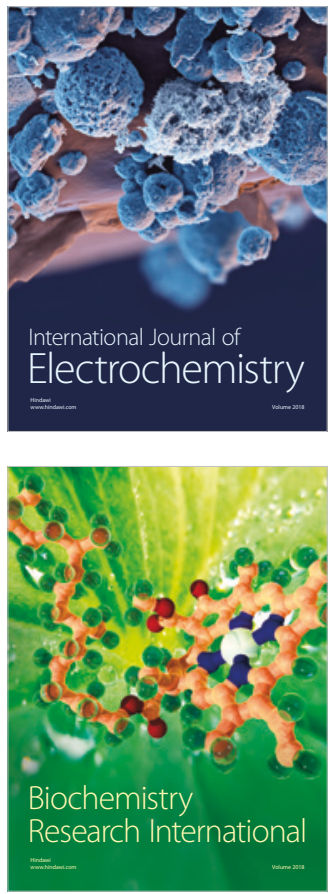